Published in "Deep Sea Research Part II:

Topical Studies in Oceanography 99(): 249-269, 2013"

which should be cited to refer to this work.

\title{
Late Weichselian deglaciation and early Holocene development of a cold-water coral reef along the Lopphavet shelf (Northern Norway) recorded by benthic foraminifera and ostracoda
}

\author{
Claudio Stalder ${ }^{\mathrm{a}, *}$, Silvia Spezzaferri ${ }^{\mathrm{a}}$, Andres Rüggeberg ${ }^{\mathrm{a}, \mathrm{b}, \mathrm{c}}$, Claudius Pirkenseer $^{\mathrm{a}}$, \\ Giordana Gennari ${ }^{\text {d }}$ \\ a Department of Géosciences, University of Fribourg, Chemin du Musée 6, 1700 CH-1700 Fribourg, Switzerland \\ ${ }^{\mathrm{b}}$ Renard Centre of Marine Geology (RCMG), Department of Geology and Soil Science, Ghent University, Krijgslaan 281 S8, B-9000 Gent, Belgium \\ ${ }^{\mathrm{c}}$ GEOMAR I Helmholtz Centre for Ocean Research Kiel, Wischhofstrasse 1-3, D-24148 Kiel, Germany \\ ${ }^{\mathrm{d}}$ Istituto Andaluz de Ciencias de la Tierra (CSIC-UGR), Av. de las Palmeras, 4, 18100 Armilla, Granada, Spain
}

\begin{abstract}
Cold-water coral (CWC) settlement in northern Norway is strongly related to the outlet-glaciers of the Fennoscandian Ice-sheet, and dating of known CWC structures show clearly post-glacial ages. Two gravity cores (POS391 559/2,277 cm long and POS391 559/3,282 cm long) were recovered on a CWC reef in the area of Lopphavet, northern Norway. Detailed investigations on lithology (sediment structures and composition), micropaleontology (foraminifera and ostracoda) and AMS ${ }^{14} \mathrm{C}$ dating on the epibenthic foraminifera Discanomalina coronata were performed on the two cores. Phosphorus analyses were performed only on core POS391 559/3. Results indicate that the whole core POS391559/2 is representative of a CWC reef environment. The base of the core is dated at 10,600 $\pm 120 \mathrm{cal}$. yr BP, thus representing one of the oldest ages of a Norwegian coral reef. Core POS391 559/3 documents the passage from a proximal glacier environment characterized by fine silty sediments with intercalation of several dropstone layers to a CWC ecosystem. The transition from the glacial to the interglacial stage is dated as old as 10,725 $\pm 205 \mathrm{cal}$. $\mathrm{yr} \mathrm{BP}$, whereas the base of the core is dated to an age of $15,300 \pm 550 \mathrm{cal}$. yr BP. Diversity of benthic foraminifera is higher within the CWC, especially in the intervals containing coral framework. Five clusters are identified based on the Bray-Curtis Similarity Term Analyses and the interpretation of data shows that they are related to different ecological settings, e.g., fluctuations of the sea-ice cover; influence of the warmer and more saline Atlantic water masses; transitional to a fully interglacial environment; well oxygenated, nutrient-rich and high current setting being conducive to CWC.

Ostracod assemblages show that these crustaceans may be also used to characterize sedimentary facies on CWC reefs.
\end{abstract}

\section{Introduction}

Cold-water corals (CWCs) were first described from Norway in the eighteenth century (Pontoppidan, 1755; Gunnerus, 1768). However, it is only from the last two decades that they have been extensively studied (e.g., Mortensen et al., 1995; Freiwald et al., 1997; Hovland et al., 1998; Rogers, 1999; Freiwald et al., 1999; Fosså et al., 2002; Lindberg and Mienert, 2005).

Recent studies (e.g., Dorschel et al., 2005; Roberts et al., 2006; Mienis et al., 2007; Huvenne et al., 2009; Thierens et al., 2010) have demonstrated a dominant oceanographic control in the development of cold-water coral reefs, mounds and ecosystems

\footnotetext{
* Corresponding author. Tel.: +412630089 79; fax: +41263009742.

E-mail address: claudio.stalder@unifr.ch (C. Stalder).
}

in the north Atlantic. The distribution of frame-building scleractinian corals seems to be climatically controlled by a variability of physical, chemical and biological parameters such as water density, temperature, salinity, pressure, currents, oxygen and nutrients availability (Roberts et al., 2006; Rüggeberg et al., 2007; Dullo et al., 2008). In particular $\delta^{15} \mathrm{~N}$ signatures of CWC tissues (Duineveld et al., 2004), experiments of feeding Lophelia in aquaria (Rapp and Sneli, 1999) or in situ observations on Norwegian reefs (Freiwald, 2002) suggest a rather large diversity in food sources. Davies et al. (2009), Thiem et al. (2006) and Mortensen et al. (2001) pointed out the preferential settlement of CWC along topographic highs and/or on locations affected by particularly strong tidal currents producing enhanced vertical flows and remobilization of suspended food particles. Furthermore, Hovland et al. (2012) demonstrated that the occurrence of Lophelia reefs on the shelf off mid-Norway are closely linked to pockmarks which 
may enhance the primary and secondary productivity through injection of nutrients to the water column and thus contribute to a continuous food supply for the living corals.

Roberts et al. (2006) and Rüggeberg et al. (2007) showed that the decrease in temperature, nutrient supply, current speed and increase in sediment input during glacial times produces unfavorable conditions for cold-water coral growth. They show that the return to interglacial/interstadial conditions is marked by the return to relatively warmer temperatures and by the reestablishment of high speeds in the circulation patterns with consequent removal of the glacio-marine deposits on topographic heights, thus producing again the favorable conditions for coldwater coral growth.

Since the last interglacial stage cold-water coral reef-like structures, dominated by $L$. pertusa, developed along the Norwegian continental shelf, from the inner of fjords to the shelf break (e.g., Dons, 1944; Mortensen et al., 1995, 2001; Freiwald et al., 1997, 1999; Hovland et al., 1997; Hovland and Mortensen, 1999; Fosså et al., 2000; Lindberg et al., 2007).

Pre-existing topographical heights on the sea floor, such as moraine ridges and iceberg plow mark levees control their distribution (Freiwald et al., 1999; Hovland and Mortensen, 1999; Mortensen et al., 2001; Freiwald et al., 2002; Fosså et al., 2005). On the Norwegian margin, from the Oslo fjord to the northernmost reefs near the Nordkapp, living corals generally colonize the top and the upper slopes of these post-glacial structures and thrive at preferential water depths of $110-400 \mathrm{~m}$ influenced by Atlantic water masses (Fosså et al., 2002; Freiwald et al., 2004; Hovland et al., 1998; Hovland and Mortensen, 1999). However, CWC reefs do also occur at shallower sites as for instance the Tautra reef complex in the Trondheimsfjord (Dons, 1944; Hovland and Mortensen, 1999; Hovland et al., 2002).

In situ, dead corals characterize the steep flanks of the reefs, while bio-eroded coral rubble accumulates around the base. These reefs provide abundant and diverse microhabitats for benthic organisms (Mortensen et al., 1995).

In Norway, the corals colonized elevated hard substrates building elongated structures that can reach heights of $40 \mathrm{~m}$ and lengths of several kilometers (Freiwald et al., 1999; Freiwald et al., 2002).

Radiocarbon ages of Lophelia fragments clearly show the development of CWC reefs at least during the last $8000-8700 \mathrm{yr}$ (Hovland and Mortensen, 1999; Hovland et al., 1998) whereas the onset of coral growth in Northern Norway was recently reported around 10,900 cal. yr BP according to López Correa et al. (2012), this latter age corresponds to the onset of the modern oceanographic conditions in the region.

This research focuses on two gravity cores (POS 391 559/2 and POS 391 559/3), which record the transition from glaciomarine sediments to an active cold-water coral reef spanning the interval from 15,300 to $2020 \mathrm{cal}$. yr BP. The micropaleontological study on benthic and planktonic foraminifera addresses the paleoenvironmental evolution of the Lopphavet region from the Latest Pleistocene to the Holocene and benthic assemblages provide assessments of suitable conditions for coral growth during the last glacial/interglacial transition.

\section{Study area and oceanography}

Lopphavet is part of the Norwegian Sea located on the shelf north of Tromso (Fig. 1). This area is surrounded by the islands of Arnoya in the south, Loppa in the southeast, and faces the main entrance to the Kaevangenfjord and Altafjord (Fig. 1). The sea-floor morphology at the study area is composed of generally shallow banks (less than $100 \mathrm{~m}$ water depth) and deep troughs reaching $380 \mathrm{~m}$ water depth (Fig. 1B and C). The bedrock at the core site consists mainly of Caledonian and Precambrian metamorphic rocks whereas further offshore Mesozoic and early Tertiary sedimentary rocks prevail (Fig. 1C, Sigmond, 1992; Winsborrow et al., 2012 and references therein). The Quaternary sediment cover is generally thin on the shelf $(<100 \mathrm{~m})$ but increases towards the shelf break and consists mainly of till deposits and successions of glaciomarine sediments (Vorren et al., 1992; Laberg et al., 2012).

During the Last Glacial Maximum, northern Norway and the continental shelf of the South-Western Barents Sea were completely covered by ice (Winsborrow et al., 2010). The Lopphavet area was at the confluence of the Fennoscandian and Barents Sea ice sheets during the last glaciation. Recent studies showed that this area has experienced intensive ice streaming during the last glacial maximum which lead to the formation of deep cross-shelf troughs on the sea-floor surrounded by moraines and banks (Vorren et al., 1998; Ottesen et al., 2008; Winsborrow et al., 2010, 2012). Lopphavet was intensively influenced by a succession of retreats and advances of three major ice-streams (Hakjerringdjupet, Fulgoybanken and Sørøya through Ice Streams; Fig. 1B) and calving glaciers during the late Weichselian (Winsborrow et al., 2012).

The Late Weichselian deglaciation of Northern Norway was rather rapid, whereas the complexity of ice-streams and the timing of the ice-sheets retreat are still poorly understood (Landvik et al., 1998; Winsborrow et al., 2010). Retreat of the Fennoscandian Ice Sheet (FIS) from the shelf break is thought to have started around 18,000 cal. yr BP (Ottesen et al., 2005; Vorren and Plassen, 2002). Available studies from this region report early glaciomarine conditions by 17,100-14,128 cal. yr BP (Hald et al., 1989; Rasmussen et al., 2007; Vorren and Plassen, 2002; Vorren et al., 1978). From the area of Ingoydjupet (Fig. 1), Junttila et al. (2010) and Aagaard-Sørensen et al. (2010) even report glacier free conditions at about 18,700 and 18,600 cal. yr BP, respectively. According to Winsborrow et al. (2012) glaciomarine conditions prevailed at the outermost Soroya Trough around ca. 15,000 cal. yr BP and at ca. 14,500 cal. yr BP at the outer Altafjorden close to Lopphavet (Fig. 1).

The surface water circulation off Norway is characterized by two northward-trending current systems (Fig. 1), the Norwegian Atlantic Current (NwAC) which is mainly a continuation of the North Atlantic Current (NAC) and the Norwegian Coastal Current (NCC), which has its main source in the Skagerrak region (Hebbeln et al., 2006). The warm and saline Atlantic water (temperature $=$ $6-9{ }^{\circ} \mathrm{C}$, salinity $=>35$ ) enters the Norwegian Sea through two major pathways, from the southwestern part by passing the Iceland-Faroe Ridge and from the southeast along the FaroeShetland Channel (Orvik et al., 2001; Orvik and Niiler, 2002). The western branch of the NwAC follows the slope topography of the Vøring Plateau towards Jan Mayen and continues further northward to the Fram Strait. The inflow along the Faroe-Shetland Channel is mainly constraint along the Norwegian shelf edge with a minor stream flowing parallel to the NCC on the shelf and converging again southwest off the Lofoten Islands (Poulain et al., 1996). The lower boundary of the NwAC reaches a water depth ranging between $500 \mathrm{~m}$ and $600 \mathrm{~m}$ (Blindheim, 1990).

The core of the eastern NwAC branch has an annual mean velocity of $30 \mathrm{~cm} / \mathrm{s}$ but may reach maximum values up to $117 \mathrm{~cm} / \mathrm{s}$ on the uneven shelf topography (Orvik et al., 2001). Around the CWC reefs, strong bottom currents prevail with velocities up to $44 \mathrm{~cm} / \mathrm{s}$ measured at the Sula reef (Eide, 1979).

Further north, the NwAC enters the Barents Sea before dividing into a stream flowing northward (West Spitsbergen Current) to Spitsbergen and a stream bifurcating to the east (North Cap Current) parallel to the northern Norwegian coast (Loeng, 1991). 


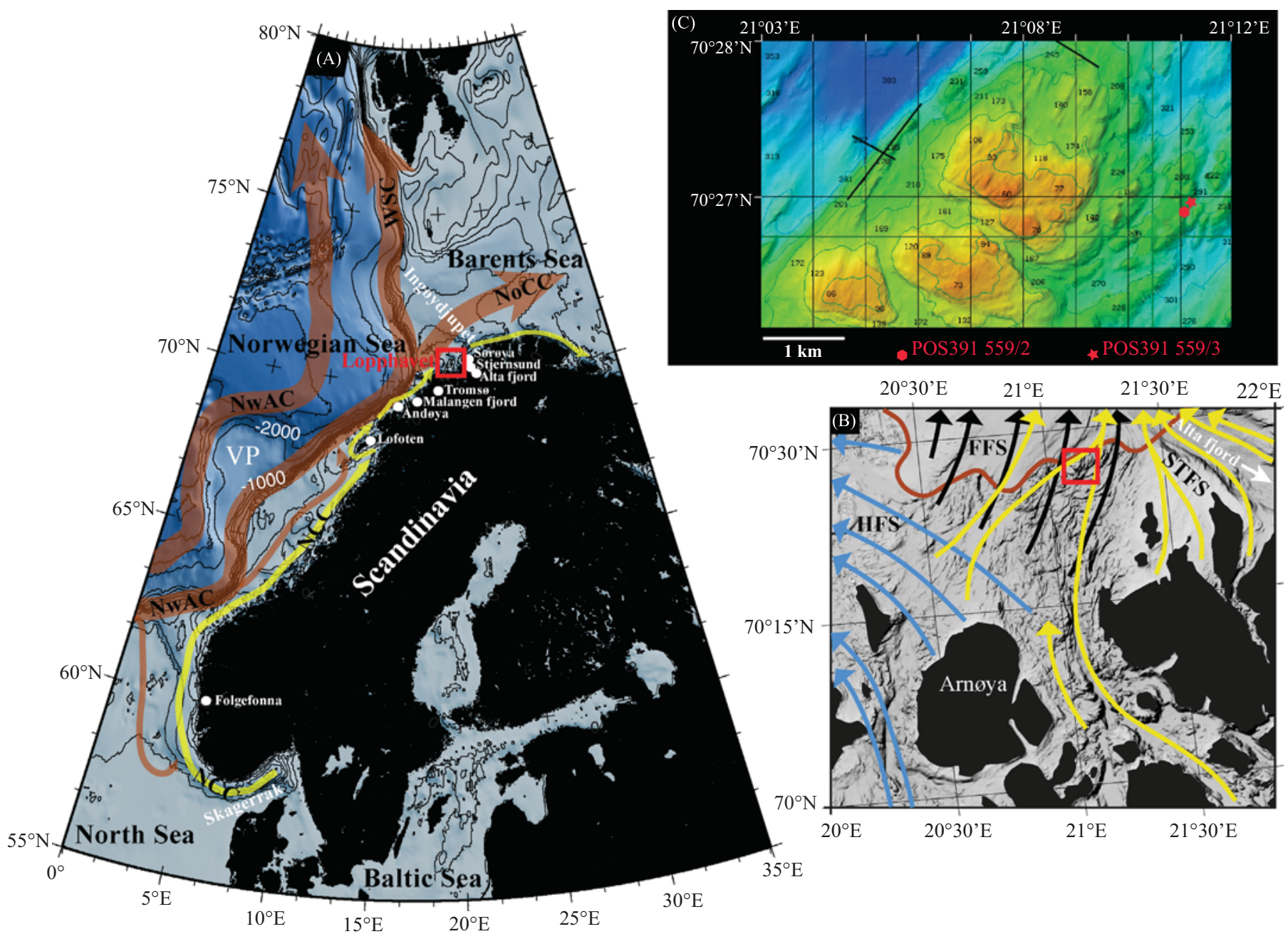

Fig. 1. (A) Location of the study area (red box) along the Norwegian continental margin. (B) Close-up of the Lopphavet sea with shaded sea-bottom topography (http://www. mareano.no/en) and surrounding islands (black). The arrows show main paleo ice-stream flows (Winsborrow et al., 2012): Håkjerringdjupet flow set (HFS, blue arrows), Fugløybanken flow set (FFS, black arrows) and Sørøya Trough flow set (STFS, yellow arrows). Indicated are also the contact between sedimentary and crystalline bedrocks (brown solid line, Winsborrow et al., 2012), the location of the sampled cold-water coral reef (red box) and the trough connecting the Stjernsund to the Altafjord (white arrow). (C) Multibeam map acquired during POSEIDON cruise 391 showing the location of the studied gravity cores. Water depth is expressed in meters. (For interpretation of the references to color in this figure legend, the reader is referred to the web version of this article.)

Off Troms, close to the study area, Sundby (1984) and Moseidjord et al. (1999) have shown that glacially eroded trenches are steering Atlantic water onshore. Such deep troughs allow the Atlantic water to enter the fjords where it is, through tidal and circulation-controlled patterns, periodically renewed (Ljoen and Nakken, 1969; Rüggeberg et al., 2011).

At its main source, the NCC consists primarily of a mixing of freshwater from the Baltic Sea outflow and from the surrounding river discharges (Mork, 1981; Sætre, 2007). Its salinity (30-34.9) and temperature $\left(3-18{ }^{\circ} \mathrm{C}\right.$ ) may strongly change with seasons (Mikalsen et al., 2001). Flowing parallel to the Norwegian shore, the NCC caps additional freshwater from the mainland. Driven by the density contrast to the Atlantic water it stretches to the shelf edge over the NwAC, getting broader and shallower in summer (Sætre et al., 1988; Garvine, 1995).

At the entrance into the Barents Sea, the density contrast between the NCC and the NwAC diminishes and increased mixing promotes the separation of the NCC in a branch flowing along the slope driven by local winds and a branch overlying the Atlantic water further offshore and more controlled by buoyancy (Skagseth et al., 2011).

In winter the NwAC and NCC mix and in combination with the trade winds and the sea floor topography produce eddies and upwelling of nutrient rich waters triggering plankton blooms (Berner and Wefer, 1994; Sætre, 1999). In summer the two currents separate again at a water depth of about $100 \mathrm{~m}$ because their density gradient prevents mixing (Sætre, 1999; MitchelsonJacob and Sundby, 2001; Mikalsen et al., 2001).

The cold-water coral ecosystems occurring between 140 and $320 \mathrm{~m}$ are under the influence of the NwAC.

\section{Materials and methods}

During R/V Poseidon cruise 391 in 2009 gravity cores POS391 $559 / 2\left(70^{\circ} 26.925 \mathrm{~N}, 21^{\circ} 11.101 \mathrm{E}\right.$; water depth $225 \mathrm{~m}$; core length $277 \mathrm{~cm})$ and POS391 559/3 (70 $26.946 \mathrm{~N}, 2^{\circ} 11.175 \mathrm{E}$; water depth $237 \mathrm{~m}$; core length $282 \mathrm{~cm}$ ) were recovered from a cold-water coral reef along Lopphavet on the northwestern Norwegian shelf (Fig. 1). A schematic representation of the core positions along the reef is provided in Fig. 2. Based on multibeam data and in situ observations (submersible dives), Fig. 2A shows the general sedimentary facies distribution around and on the reef structure. A close-up of the core location area displays internal small-scale variations of the main sedimentary facies (Fig. 2B). The cores were 
stored at $4{ }^{\circ} \mathrm{C}$, opened, described and sampled at the GEOMAR I Helmholtz Centre of Ocean Research Kiel.

\subsection{Micropaleontological study}

Samples for micropaleontological analyses (benthic and planktonic foraminifera and ostracods) were taken at $3 \mathrm{~cm}$ interval for both cores and processed following standard procedures (see Schönfeld et al., 2012 and references therein). They were weighted, and then washed through $63 \mu \mathrm{m}, 125 \mu \mathrm{m}$ and $250 \mu \mathrm{m}$ sieves to obtain three size fractions. Residues were dried at room temperature and weighted. When a residue contained sensibly more than the target number of 300 specimens of foraminifera in a single fraction, it was split using a dry splitter. A minimum of 200 specimens were identified at species level, glued on Plummer cell-slides and counted for each fraction (about 900 specimens per sample).

When samples contained less than 200 specimens per fraction, all specimens were counted. All 94 samples from core POS391 559/ 3 were analyzed for their micropaleontological content, whereas a

(A)
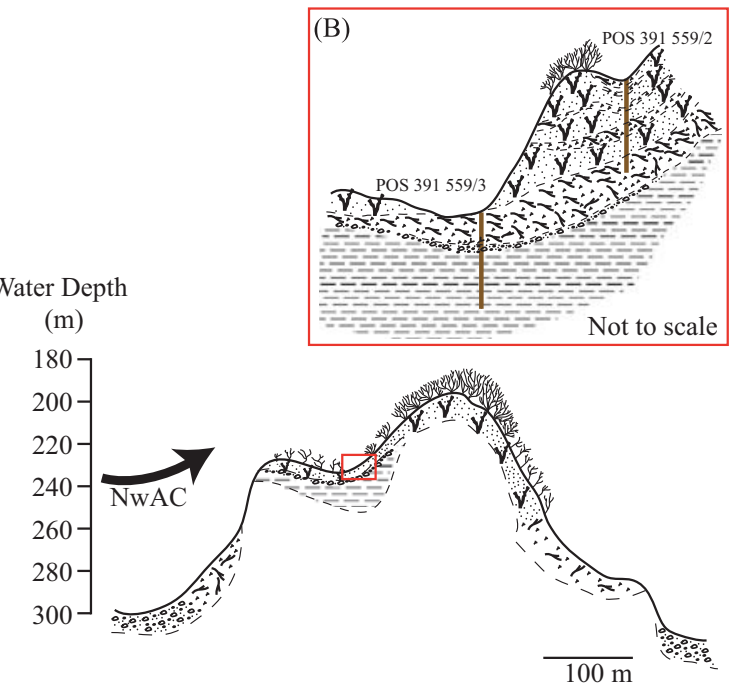

$\checkmark$ Coral framework with high abundance of bivalves/gasteropods and serpulids oral debris with fine to coarse grained sediments (mainly reworked) Dropstone layer at the base of the corals

Glaciomarine sediment with dropstone layers

Fig. 2. Sketch of the sampled cold-water coral reef. (A) Topography and main sedimentary facies are based on in situ observations with the Jago submersible and bathymetric data (modified after Freiwald et al., 2002; Spezzaferri et al., 2013). (B) Close-up of the studied cores along the reef. Sedimentary facies are according to the core lithology. total of 31 samples chosen according to lithological changes were investigated for core POS391 559/2. The identified species of benthic foraminifera are listed in Appendices 3 and 4. The two cores are stored at GEOMAR in Kiel and the foraminiferal collection is stored at the Department of Geosciences, University of Fribourg.

Raw data of benthic foraminifera were statistically treated using the Software PRIMER 6 (Clarke and Warwick, 2001). The Fischer-alpha index was obtained by univariate statistical analysis.

The data set was also double-square root transformed to limit the contribution of most abundant and ubiquitous species (Field et al., 1982) and the Bray-Curtis (dis-)Similarity Term Analysis was calculated (Clifford and Stephenson, 1975). The same similarity matrix used for Bray-Curtis (dis-)similarities was used also to obtain the non-metric MultiDimensional Scaling-nMDS plot (Kruskal, 1964; Kruksal and Wish, 1978). An overview of the characteristics of the nMDS plot can be found in (Warwick and Clarke, 1991; Clarke and Warwick, 2001) and example of its application on foraminiferal data in Basso and Spezzaferri (2000) and Margreth et al. (2009).

The nMDS plot was interpreted according to the Similarity Percentage Analysis (SIMPER), which highlights the contribution of each species to the total average similarity and dissimilarity between different groups and within single groups. Taxonomic notes, and quantitative data of benthic foraminifera are reported in Appendices 1 and 2 .

Ostracods were investigated using the same samples previously studied for foraminifera and each individual specimen was identified at species level. Appendix 2 reports the list of the identified species.

Both cores have also been investigated for their main biogenic components $(\mathrm{MBC})$ at $3 \mathrm{~cm}$ interval including sponge spicules $\left(\mathrm{SiO}_{2}\right)$, radiolarians, serpulids, echinoderm fragments (ophiurid ossicles and shields, urchin spines), bryozoans and marine shells (brachiopods, bivalves, gastropods).

\subsection{AMS ${ }^{14} \mathrm{C}$ dating}

Radiocarbon dating was performed at the Eidgenössische Technische Hochschule (ETH) Zürich using the accelerator mass spectrometry (AMS) technique. Table 1 reports the dated samples, corrected and calibrated (AD 1950).

From selected samples, benthic foraminifera were picked until at least $5-10 \mathrm{mg}$ of pure carbonate were obtained. The species Discanomalina coronata, which lives attached to a hard substrate and associated to the cold-water coral ecosystems (Margreth et al., 2009) was chosen whenever possible. Alternatively mixed benthic species were picked. Specimens were cleaned in ultrasounds to remove eventual contamination. They were dissolved in concentrated phosphoric acid (Hajdas et al., 2004a) and the extracted carbon dioxide was converted into graphite as described by Hajdas et al. (2004b). A reservoir age correction of 390 years with a

Table 1

Radiocarbon dates, calibrated ages and mean sedimentation rates of core POS 391 559/2 and POS 391 559/3.

\begin{tabular}{|c|c|c|c|c|c|c|c|}
\hline Lab. code & Core number & $\begin{array}{l}\text { Core depth } \\
(\mathrm{cm})\end{array}$ & Material & $\begin{array}{l}{ }^{14} \mathrm{C} \text { age }(\mathrm{yr} \mathrm{BP}) \\
\text { (reservoir corrected) }\end{array}$ & $\begin{array}{l}95.4 \% 2 \sigma \mathrm{cal} . \\
\text { age ranges }(\mathrm{yr})\end{array}$ & $\begin{array}{l}\text { Age used } \\
\text { (cal. yr BP) }\end{array}$ & $\begin{array}{l}\text { Sedimentation } \\
\text { rate }(\mathrm{cm} / \mathrm{kyr})\end{array}$ \\
\hline ETH-42972 & POS391 559/2 & 1 & D. coronata & $2405 \pm 40$ & $2170-1870$ & $2020 \pm 150$ & \\
\hline ETH-42973 & POS391 559/2 & 226 & D. coronata & $9130 \pm 50$ & $10,120-9660$ & $9890 \pm 230$ & 28.6 \\
\hline ETH-46546 & POS391 559/2 & 274 & D. coronata & $9730 \pm 40$ & $10,715-10,480$ & $10,600 \pm 120$ & 67.6 \\
\hline ETH-42969 & POS391 559/3 & 1 & D. coronata & $6350 \pm 45$ & $6950-6650$ & $6800 \pm 150$ & \\
\hline ETH-42970 & POS391 559/3 & 64 & D. coronata & $9815 \pm 50$ & $10,930-10,520$ & $10,725 \pm 205$ & 16.1 \\
\hline ETH-42971 & POS391 559/3 & $274-277$ & $\begin{array}{l}\text { N. labradorica, } \\
\text { C. pachyderma }\end{array}$ & $13,200 \pm 60$ & $15,850-14,750$ & $15,300 \pm 550$ & 45.9 \\
\hline
\end{tabular}


regional delta $R$-value of $10 \pm 35$ (Reimer et al. 2009) was applied to obtained radiocarbon conventional ages, which were then calibrated using the program OxCal 3.10 (Bronk Ramsey, 2005). All ages are given in calendar years before present (cal. yr BP).

\subsection{Phosphorus analyses}

A 5-step sequential extraction technique following the SEDEX method of Ruttenberg (1992) was applied on the 94 samples of core POS391 559/3 to quantify 5 different phosphorus phases contained in the sediment. Around $80 \mathrm{mg}$ of dry bulk sediment were ground to pass through a $150 \mu \mathrm{m}$ mesh sieve. This technique allows to distinguish the contribution of loosely-bound phosphorus, authigenic apatite, detrital apatites (igneous, metamorphic and sedimentary) and organic-bound phosphorus. In this study, only detrital phosphorus data will be presented and discussed. A whole characterization of the phosphorus fractions from core POS391 559/3, including organic carbon content and mineralogy determination of the IRD layers is part of a complementary study. Since detrital phosphorus occurs in detrital grains it has often been used to estimate the variability of detrital inputs (river and glacially related discharges, eolian inputs) to the surrounding sedimentary environments (Louchouarn et al., 1997; Tamburini et al., 2002). Extraction was performed at the University of Fribourg and samples were measured with a Bio-Tek Uvikon XS spectrophotometer using the molybdate blue method (Grasshoff et al., 1983).

\subsection{Sedimentology}

Ice-rafted debris (IRD) and grain size distribution were systematically evaluated in both cores using the largest fraction $(>250 \mu \mathrm{m})$ of the residues prepared for micropaleontological investigations (Fig. 3). The IRD were counted in the $>250 \mu \mathrm{m}$ and $>1 \mathrm{~mm}$ size fractions following Watkins et al. (1974) and standardized for $1 \mathrm{~g}$ of the total dry weight of each sample. Grain size distribution was obtained by weighting the three mesh sieves residues used for micropaleontological analyses and is expressed in percentage of the total dry sediment of the samples (Fig. 3). Distinction between coral rubble and coral framework is based on core description and X-ray tomography.

\section{Results}

\subsection{Lithology, biogenic components and IRD content}

\subsubsection{Core POS391 559/2}

Scleractinian coral fragments (mainly $L$. pertusa) and the mentioned biogenic components (sponge spicules $\left(\mathrm{SiO}_{2}\right)$, radiolarians, serpulids and echinoderm fragments) are continuously present all over the $277 \mathrm{~cm}$ long sediment core (Fig. 3A). Three lithological units can be recognized. The sediments from $229-277 \mathrm{~cm}$ belong to lithological unit P-1 and consist of coral rubble in a dark olive brown (3/3 2.5y) muddy silt matrix. The lithological unit P-2 ranges from $86-228 \mathrm{~cm}$ and is characterized by a succession of coral rubble and coral framework intervals in a grayish brown (4/2 $2.5 y$ ) sandy mud. Dense and interconnected coral branches occur from the base of lithological unit P-2 to $180 \mathrm{~cm}$ and from 103$137 \mathrm{~cm}$ core depth. The intervals from $137-180 \mathrm{~cm}$ and $86-103 \mathrm{~cm}$ contain dislocated coral fragments (rubble). Sample $211 \mathrm{~cm}$ contains a large abundance of serpulids. Any sedimentary structures have been identified in P-2 and P-3. The lithological unit P-1 from $85 \mathrm{~cm}$ to the top of the core consists of light olive green (5/3 2.5y) muddy sand (sand lenses) with a visible coarsening up starting from $40 \mathrm{~cm}$ upwards. In this lithological unit, coral framework has been identified from $47-86 \mathrm{~cm}$ and $17-29 \mathrm{~cm}$ core depth. Coral rubble occurs from $29-47 \mathrm{~cm}$ and from $17 \mathrm{~cm}$ to the top of the core. Low abundance of IRD is observed in P-3 (up to 4 debris/g of sediment at $264 \mathrm{~cm}$ ) and almost no IRD was found in P-2 (up to 1 debris/g of sediment at $220 \mathrm{~cm}$ ). The highest content of IRD of 9 particles/g of sediment was found at $1 \mathrm{~cm}$ core depth. Grain size distribution shows a gradual decrease of the finer fraction $(<63 \mu \mathrm{m})$, from the base of the core to the top passing from a matrix with more than $95 \%$ of silts/clays at $271 \mathrm{~cm}$ to less than $25 \%$ at $1 \mathrm{~cm}$.

\subsubsection{Core POS391 559/3}

Three different lithological units can be identified in Core POS 391 559/3 (Fig. 3B).

The sediments from $68-282 \mathrm{~cm}$ belong to the lithological unit $\mathrm{G}$, which is characterized by 4 IRD layers from $264-282 \mathrm{~cm}$ (L1), $184-191 \mathrm{~cm}$ (L2), $132-138 \mathrm{~cm}$ (L3) and 67-94 cm (L4) in a gray (5/ $12.5 \mathrm{y}$ ) silty mud matrix without any coral fragments and apparent sedimentary structures. Scarce biogenic components are present along lithological unit $\mathrm{G}$ with echinoderm fragments present from
(A)

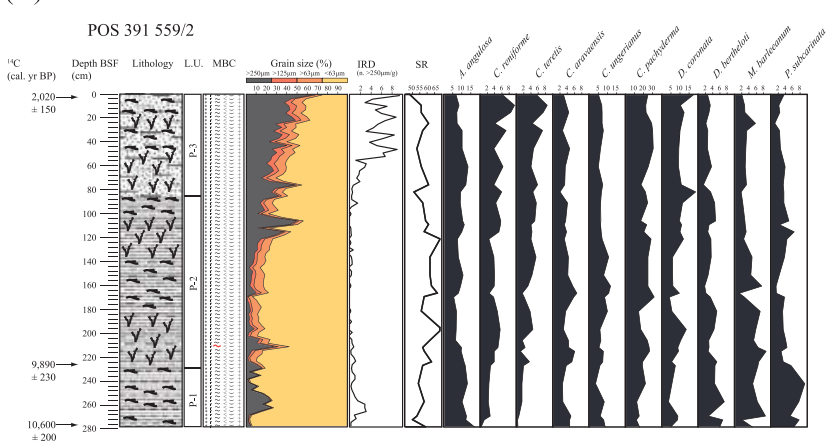

(B)

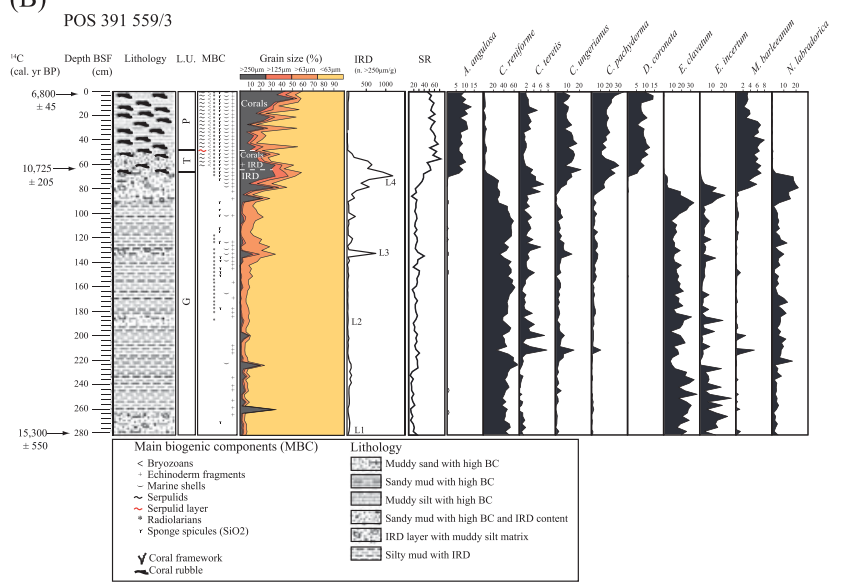

Fig. 3. Lithological log of core POS $391559 / 2$ (A) and POS $391559 / 3$ (B) plotted versus grain size distribution, IRD, main biogenic components (MBC), ${ }^{14}$ C ages (cal. yr BP). Also shown are species richness of benthic foraminifera (SR) and the distribution of the ten most common benthic foraminiferal species in both cores (in \% of the total fauna). 
(B)

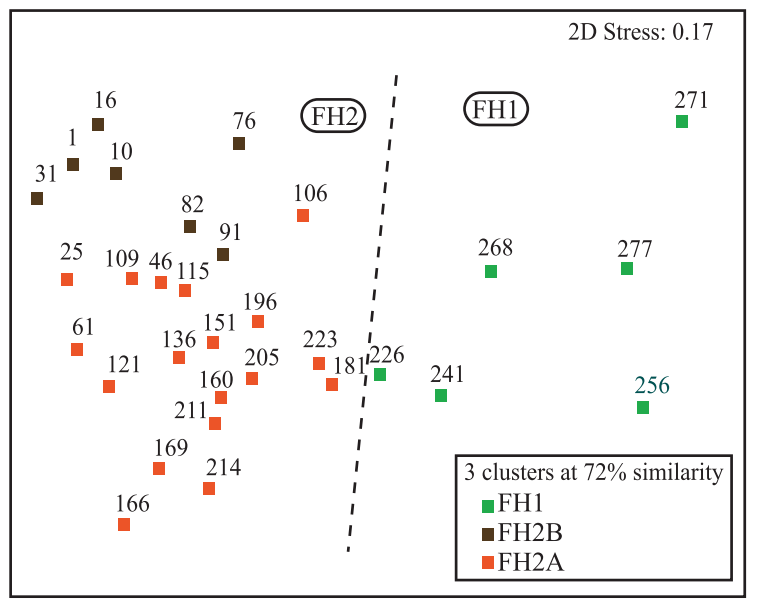

(A)

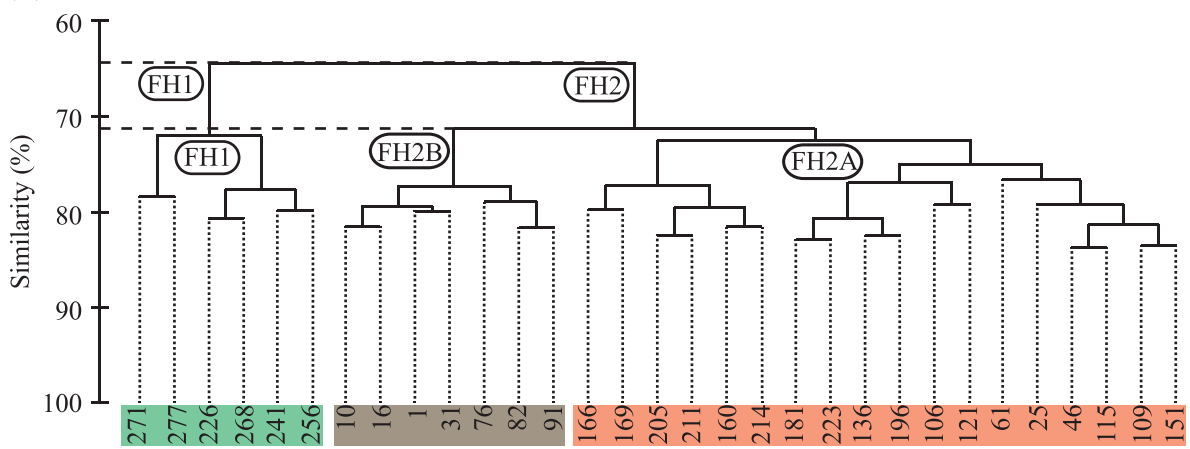

Fig. 4. (A) Dendrogram based on the Bray-Curtis (di)-similarity matrix of the benthic foraminifera data set. Dashed horizontal lines separate high level clusters (64\%) from lower level clusters (72\%). Dashed vertical lines highlight non-significantly different cluster levels (SIMPROF, Similarity Profile test). (B) Non-metric MultiDimensional Scaling (nMDS) plot obtained from the Bray-Curtis (di)-similarity matrix of the benthic foraminifera data set. Dashed line separates cluster FH1 from cluster FH2.

the base of the core and abundant radiolarians, sponge spicules and marine shells between $118-187 \mathrm{~cm}$. The first occurrence of a marine shell (bivalve) was observed at $223 \mathrm{~cm}$. The IRD record (Fig. 3B) shows a continuous distribution from the base of the core up to $49 \mathrm{~cm}$ with a positive peak (up to 900 debris/g of sediment) (L3) and a maximum for L4 (up to 1300 debris/g of sediment). These 4 IRD layers (L1-L4) contain angular to subrounded dropstones with different mineralogical composition (e.g., granite, gneiss, old red sandstone) and different size (up to $6 \mathrm{~cm}$ in diameter). Few IRD (0-16 debris/g of sediment) is also present in lithological unit $\mathrm{P}$ with a slightly higher contribution in the first $7 \mathrm{~cm}$ (up to 16 debris/g of sediment at $4 \mathrm{~cm}$ core depth). Grain size distribution shows a nearly gradual decrease of silts and clays along unit G, from values of $96 \%$ at $247 \mathrm{~cm}, 65 \%$ at $133 \mathrm{~cm}$ and $40 \%$ at $67 \mathrm{~cm}$ whereas lithological units $\mathrm{T}$ and $\mathrm{P}$ show an alternation between sandy and muddy levels.

The lithological unit $\mathrm{T}$ ranges from $49-67 \mathrm{~cm}$ and consists of coral fragments (coral rubble; mainly $L$. pertusa) and shows a continuous distribution of biogenic components (e.g., gastropods, bivalves, brachiopods, radiolarians, echinoderms and abundant sponge spicules) except for the serpulids and the bryozoans occurring for the first time at $61 \mathrm{~cm}$ depth. This lithological unit contains a large number of well-sorted subangular IRD (up to 800 particles per gram of sediment) in a coarse light olive green $(5 / 3$ $2.5 \mathrm{y}$ ) silty matrix. The transition from the lithological unit $\mathrm{T}$ to $\mathrm{P}$ coincides with a drastic increase of serpulids (Fig. 3B) at $49 \mathrm{~cm}$.

From $48 \mathrm{~cm}$ up to the top of the core sediments are characterized by coral rubble (mainly Lophelia pertusa) mixed with other different biogenic fragments (e.g., gastropods, bivalves, brachiopods, bryozoans, serpulids, radiolarians, echinoderms and abundant sponge spicules) in an olive brown (4/3 2.5y) sandy mud matrix and correspond to the lithological unit $\mathrm{P}$.

\section{2. $A M S{ }^{14} C$ chronology}

Three AMS ${ }^{14} \mathrm{C}$ ages obtained from $D$. coronata provide an age of $10,600 \pm 120$ cal. yr BP for the base for core, $9890 \pm 230$ cal. yr BP at $226 \mathrm{~cm}$ and $2020 \pm 150$ cal. yr BP for the uppermost part of core POS391 559/2.

Age assessment of core POS391 559/3 is based on two AMS ${ }^{14} \mathrm{C}$ ages obtained from Discanomalina coronata (benthic foraminifer) and one age based on mixed benthic foraminifera species. The deeper sample $(274-277 \mathrm{~cm})$ was too small for monospecific dating, therefore mixed benthic foraminifers were picked. Ages and sedimentation rates are shown in Table 1.

The sediments at the base of the core are dated as old as $15,300 \pm 550$ cal. yr BP.

The sample immediately below the interval containing coldwater coral fragments displays an age of $10,725 \pm 205$ cal. yr BP while the sediments at the top of the core are dated at $6800 \pm$ 150 cal. yr BP.

\subsection{Foraminiferal and ostracods abundance and distribution}

Micropaleontological analyses on core POS391 559/2 and POS391 559/3 provided a dataset of 176 benthic foraminifera species (Appendices 3 and 4). Abundance (in \% of total abundance) and distribution of the ten most common species 


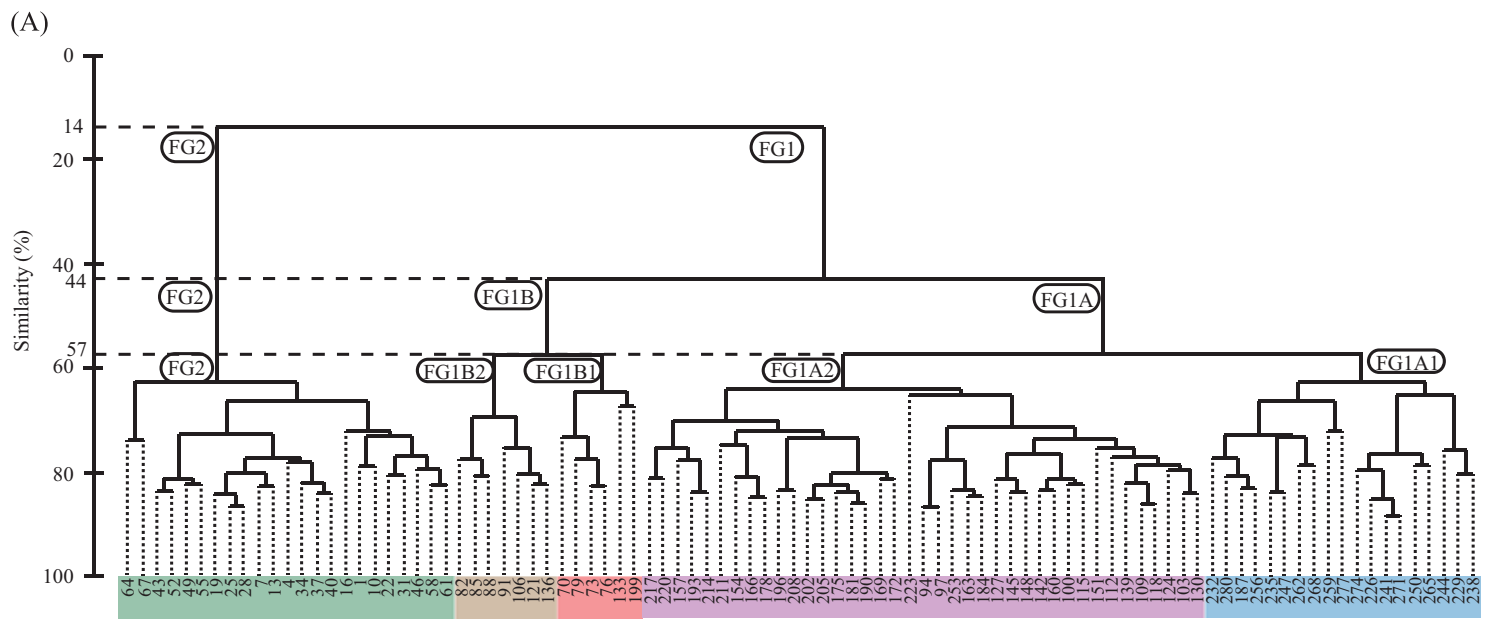

(B)

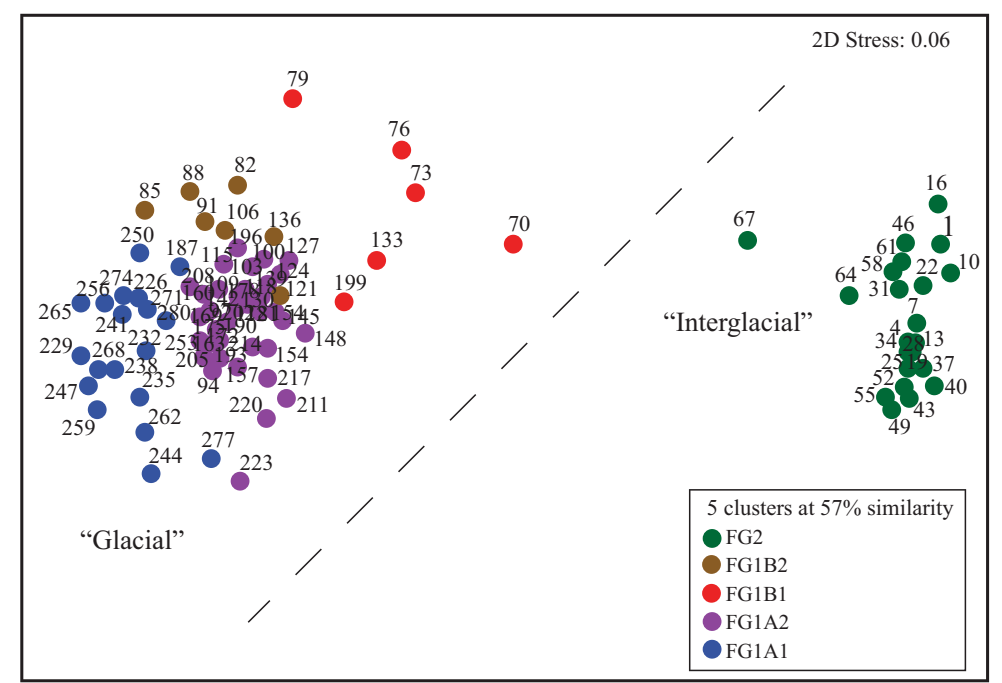

Fig. 5. (A). Dendrogram based on the Bray-Curtis (di)-similarity matrix of the benthic foraminifera data set. Dashed horizontal lines separate high level clusters (14\%) from lower level clusters (44\% and 57\%). Dashed vertical lines highlight non-significantly different cluster levels (SIMPROF, Similarity Profile test). (B) Non-metric MultiDimensional Scaling (nMDS) plot obtained from the Bray-Curtis (di)-similarity matrix of the benthic foraminifera data set. Dashed line separates Interglacial/Coral facies cluster FG2 from the glaciomarine clusters FG1A1, FG1A2, FG1B1 and FG1B2.

recorded in the two cores are shown in Fig. 3. Planktonic specimens have also been counted and eight species (Globigerina bulloides, Globigerinita glutinata, Globigerinita uvula, Neogloboquadrina dutertrei, Neogloboquadrina incompta, Neogloboquadrina pachyderma, Strepochilus tokelaue, Turborotalia quinqueloba) are identified in both cores. Because of their extremely low abundance in core POS391 559/3, planktonic foraminifera will not be discussed in further detail.

While the list of references dealing with the subject of temperate to arctic (deep) marine ostracods is quite extensive, only one overview paper recording ostracods from cold-water coral mounds has been published so far (Coles et al., 1996). The high-resolution sampling in both of our investigated cores represents a unique opportunity to investigate the transition of Latest Pleistocene to Holocene ostracod assemblages in detail in a highdiversity environment.

The low number of specimens and the presence of a relatively high ratio of instars renders a quantitative statistical analysis of the ostracod assemblages unfeasible. Therefore a subdivision of faunal assemblages is based on a qualitative analysis of lowest and highest occurrences (range charts) and simple species richness curves.

\subsubsection{Core POS391 559/2}

The ten most abundant benthic foraminifera species of core POS391 559/2 are continuously present from the base to the top of the core (Fig. 3A). The distribution of epifaunal species Cibicidoides pachyderma and Discanomalina coronata follows an increasing trend toward the top. Cibicidoides pachyderma has remarkably lower values in the interval $181-277 \mathrm{~cm}(12-26.2 \%)$ than in the interval $1-169 \mathrm{~cm}(17-31 \%)$, whereas $D$. coronata is less abundant from 136 to $277 \mathrm{~cm}$ (3.7-13.5\%) than in the overlying sediments (9.4-18.6\%). A considerable positive peak $(+7.2 \%)$ of $D$. coronata occurs around $82 \mathrm{~cm}$ coinciding with a change in lithology (base of P-1) and with a drop in diversity down to 51 species.

The abundance curves of the infaunal species Cassidulina reniforme and Cassidulina teretis clearly show an increasing trend, similar to both species from the base toward the top of the core. The lowest abundances are observed from 226 to $277 \mathrm{~cm}$ (values between $0.3-2.8 \%$ and $0.3-1.9 \%$, respectively) and the highest abundances are in the uppermost part with a peak at $10 \mathrm{~cm}$ (up to $9.5 \%$ and $8.5 \%$ respectively for both species). At $121 \mathrm{~cm}$ and $166 \mathrm{~cm} \mathrm{C}$. reniforme becomes temporarily less abundant while benthic foraminifera species richness shows two major peaks of diversity (69 species at $121 \mathrm{~cm}$ and 67 at $166 \mathrm{~cm}$ ). Such a negative 
correlation seems to develop from $118 \mathrm{~cm}$ to the top of the core, where $C$. reniforme clearly increases in abundance while the SR becomes lower. Highest abundances of $C$. reniforme and $C$. teretis are observed in P-1 where the IRD input is important.

The abundance curves of Angulogerina angulosa, Discorbinella bertheloti, Melonis barleeanum and Pullenia subcarinata show an opposite pattern with a decreasing trend toward the top of the core. The absolute maximum for each of these species is recorded within P-3. In particular, the two infaunal species $M$. barleeanum and $P$. subcarinata are consistently present and more abundant in the finest sediments of the core (P-3) reaching values up to $8.5 \%$ ( $M$. barleeanum) and 9.3\% (P. subcarinata). They progressively decrease in abundance in the coarser sediments. The lowest abundance of $M$. barleeanum (1.3\%), recorded at $166 \mathrm{~cm}$, corresponds to generally lower values of the other infaunal species (e.g., A. angulosa, C. reniforme, C. teretis, P. subcarinata). Epibenthic species Cibicides aravaensis and Cibicides ungerianus show a relatively constant distribution in the whole core contributing with values from $2 \%$ to $6.6 \%$ and $3.5 \%$ to $11.8 \%$. Fisher's alpha index of the benthic foraminifera shows values ranging from 36.3 at $1 \mathrm{~cm}$ to 103.6 at $196 \mathrm{~cm}$ core depth. Highest values are reached within the sediments belonging to coral framework intervals. Fisher's alpha index generally shows a positive correlation to coral framework (Fig. 6).

The lowest sample in proximity to the Pleistocene-Holocene boundary is ostracod-barren (Fig. 6). In subsequent samples we distinguish three assemblages (OA1-3), with OA1 further subdivided (Fig. 6). Species richness increases rather gradually from the oldest to the youngest sample, with a first maximum in OA2 (9 taxa) and a second in OA3 (10 and 11 taxa). Only Neonesidea inflata occurs in all samples. OA1 (205$271 \mathrm{~cm}$ ) is characterized by the stepwise (OA1a-b) establishment of the most common and long-ranging species (Cytherella spp. and Neonesidea inflata, later Pterygocythereis spp.), leading to a moderate increase in species richness (2-4 taxa). In OA2 (46-241 cm) the last common genus (Krithe spp.) and accessory taxa (e.g., Bythocypris affinis, Argilloecia conoidea, Cytheropteron spp.) appear, with the latter occurring in a rather scattered pattern. OA $3(0-46 \mathrm{~cm})$ is characterized by the simultaneous lowest occurrence of Thaerocythere crenulata and Muellerina abyssicola and the disappearance of Pterygocythereis muconata. The last record of Cytherella serratula is in mid-OA3 (Fig. 6).

\subsubsection{Core POS 391 559/3}

The abundance curves of the ten most abundant benthic foraminifera species clearly show (Fig. 3B) two major distribution patterns in this core.

Lithological unit $G$ is characterized by high abundances of Cassidulina reniforme, Elphidium excavatum f. clavata, Elphidium incertum and Nonionellina labradorica which contribute with at least $75 \%$ to the total fauna. The dominant species $C$. reniforme has a relatively homogenous distribution along lithological unit $\mathrm{G}$ with highest frequencies between 91 and $282 \mathrm{~cm}$ (up to 65\% at $223 \mathrm{~cm}$ ). This species decreases considerably from $30 \%$ at $88 \mathrm{~cm}$ to less than $3 \%$ at $64 \mathrm{~cm}$. The distribution of Elphidium excavatum f. clavata and E. incertum is relatively similar. They are abundant and frequent in the lowest part of the core $(223-282 \mathrm{~cm})$ with values up to $35 \%$ at $247 \mathrm{~cm}$ for E. excavatum f. clavata and $27 \%$ at $250 \mathrm{~cm}$ for E. incertum. From $223 \mathrm{~cm}$ an important decrease in abundance for both species occurs (values are less than $10 \%$ for E. excavatum f. clavata and $1 \%$ for E. incertum). Both species show then a strong increase in the upper part of the core just before their simultaneous disappearance at the base of the coral debris $(64 \mathrm{~cm})$. This pattern and decline occurs at different depths/times: E. excavatum f. clavata starts to increase from $106 \mathrm{~cm}$ and declines from $88 \mathrm{~cm}$, whereas $E$. incertum incre-
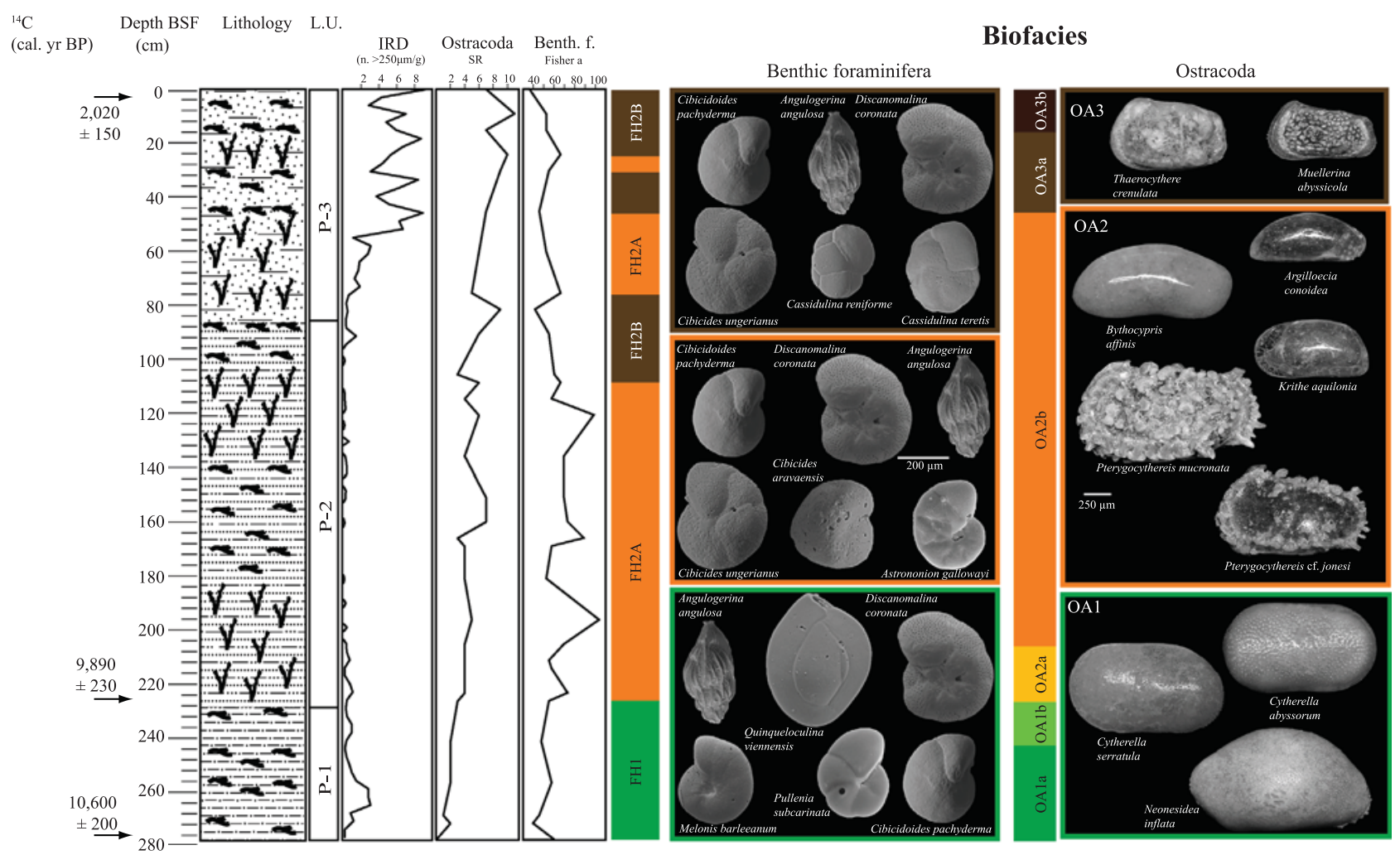

Fig. 6. Lithostratigraphy of core POS391 559/2 plotted against ostracoda species richness (SR) and Fisher's alpha index of benthic foraminifera and the assemblages obtained from the benthic foraminifera and ostracoda compositional data set. 
ases from the base of the IRD layer L4 $(94 \mathrm{~cm})$ and decreases from $85 \mathrm{~cm}$.

Nonionellina labradorica shows a continuous distribution from the base of the core to the top of lithological unit T $(49 \mathrm{~cm})$. Within lithological unit $\mathrm{G}$, the lowest abundances of $N$. labradorica are observed from 223 to $282 \mathrm{~cm}(1-5 \%)$ and at the base of the dropstone layer L4 (less than $2 \%$ ).

A drastic increase in $N$. labradorica co-occurs with IRD layer L4 and coincides with the increase of E. incertum. The maximum abundance of $N$. labradorica $(22 \%)$ is reached at $79 \mathrm{~cm}$ and a remarkable decrease is observed from $70 \mathrm{~cm}(18 \%)$ to $67 \mathrm{~cm}(3 \%)$ corresponding to the first occurrence of $A$. angulosa and $D$. coronata $(67 \mathrm{~cm})$. This species is observed in lithological unit $\mathrm{P}$ only in a few samples with very low contribution (less than $0.5 \%$ ).

An opposite distribution pattern prevails for Discanomalina coronata and Angulogerina angulosa. Discanomalina coronata is completely absent in lithological unit $\mathrm{G}$, whereas A. angulosa is found in only seven samples with isolated specimens. However, both species are abundant in the interval containing coral fragments (P and $\mathrm{T} ; 1-67 \mathrm{~cm}$ ).

A similar distribution pattern is observed for the two epibenthic species $C$. ungerianus and $C$. pachyderma. Their abundances increase stepwise to the top of the core with values lower than $4 \%$ between 217 and $282 \mathrm{~cm}$, up to $15 \%$ from 85 to $217 \mathrm{~cm}$ and higher than $30 \%$ in the uppermost part of the core. Melonis barleeanum follows this trend with sporadic occurrences along lithological unit $\mathrm{G}$ and a continuous presence from $85 \mathrm{~cm}$ to the top of the core. This species is continuously present but never abundant (less than $2 \%$ ) from 82 to $217 \mathrm{~cm}$ and drastically increases from $82 \mathrm{~cm}$ to $40 \mathrm{~cm}$, where the curve shows the highest abundances (up to $8 \%$ at $40 \mathrm{~cm}$ ).

Furthermore, the record of $M$. barleeanum reveals two major peaks at $199 \mathrm{~cm} \mathrm{(4 \% )} \mathrm{and} 208 \mathrm{~cm}(6 \%)$ as well as a clear decrease in abundance from $28 \mathrm{~cm}$ upward.
The distribution pattern of Cassidulina teretis is slightly different with scattered occurrences from 217 to $282 \mathrm{~cm}$ (abundances less than 2\%) and higher frequencies between 67 and $214 \mathrm{~cm}$ (up to $8 \%$ ). Two major abundance peaks occur at $211 \mathrm{~cm}$ and $199 \mathrm{~cm}$ coinciding with sporadic higher abundances of $M$. barleeanum.

In lithological unit $\mathrm{P}, \mathrm{C}$. teretis has relatively constant abundances in the interval $34-61 \mathrm{~cm}(1.1-1.9 \%)$ before increasing sensibly between 1 and $31 \mathrm{~cm}(1.8-5 \%)$.

Benthic foraminifera species richness displays an identical stepwise increasing distribution pattern as observed for the abundance of single species e.g., C. ungerianus, C. pachyderma and M. barleeanum. The lowest diversity occurs from 229 to $282 \mathrm{~cm}$ (13 to 27 species) followed by remarkably higher diversity from 79 to $226 \mathrm{~cm}$ (16-40 species) and highest species richness (30-72 species) occurs from 1 to $76 \mathrm{~cm}$. A considerable higher diversity (40 species) is identified at $133 \mathrm{~cm}$ within IRD layer L3. A similar trend is observed in correspondence to the top of IRD layer L4 (from $67-79 \mathrm{~cm}$ ). Fisher's alpha index of the benthic foraminifera from this core shows the same gradual and stepwise increase from the base to the top of the core with lowest values in the interval 226-280 (4 at $229 \mathrm{~cm}$ ) and highest scores within the sediments containing coral fragments (up to 115.3 at $55 \mathrm{~cm}$ core depth). However, in lithological unit P Fisher's alpha index clearly decreases towards the top of the core (Fig. 7).

The stratigraphic distribution of ostracod species (Fig. 7) allows the distinct separation of two main assemblages, referred to as "glacial" (OGA, 67-280 cm) and "interglacial" (OIA, 0-67 cm). No species of the former occur in the latter, except for fragmented or badly preserved, presumably reworked rare specimens in the lowermost samples of OIA1.

The "glacial" assemblage is subdivided in four sub-assemblages. OGA1 $(133-280 \mathrm{~cm})$ is characterized by an extremely low number of specimens, a low species richness (max. 2 taxa) and a high number of ostracod-barren samples. Within OGA1 there are two

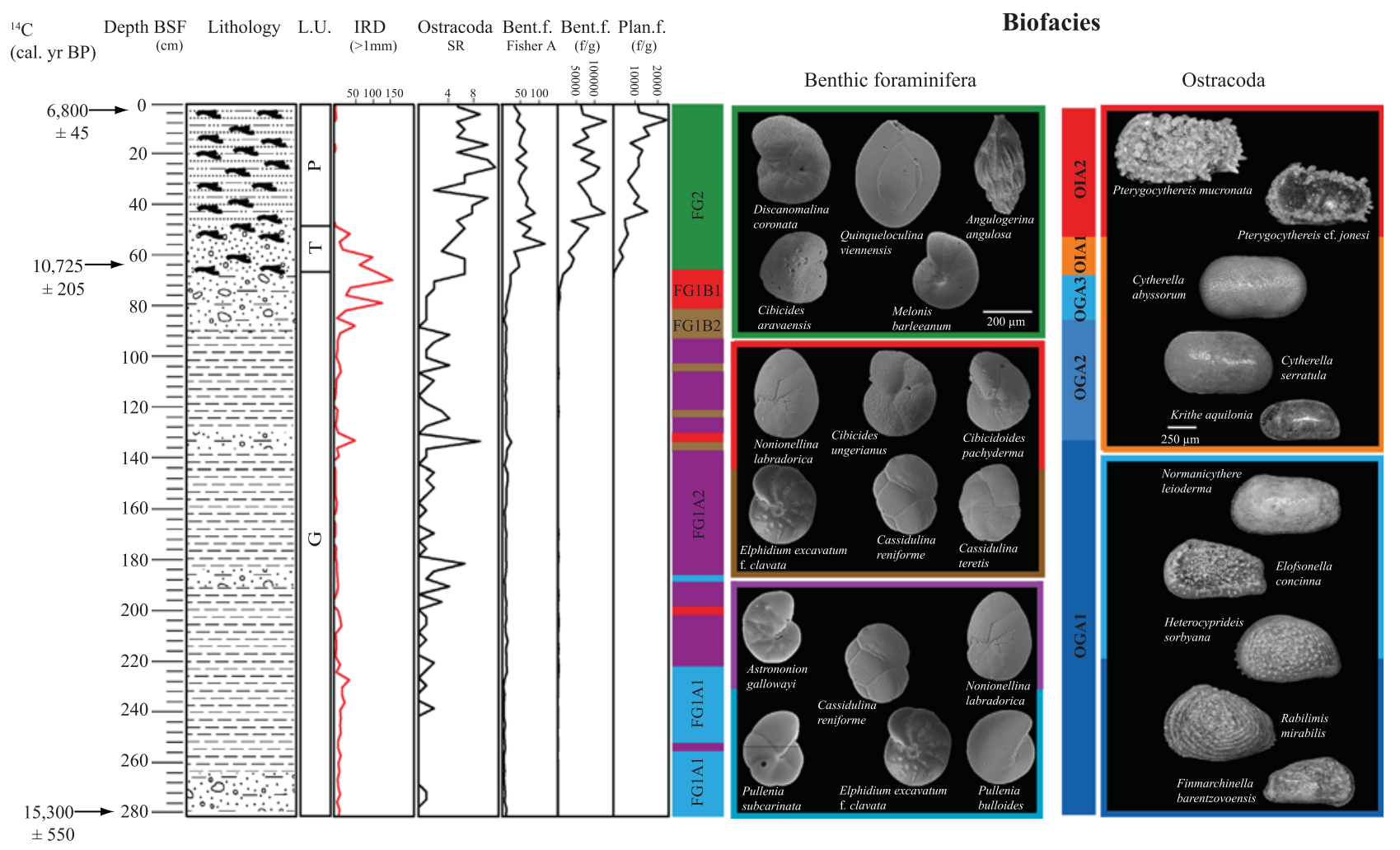

Fig. 7. Lithostratigraphy of core POS391 559/3 plotted against ostracoda species richness (SR) and Fisher's alpha index of benthic foraminifera, specimens per gram of sediment, and the assemblages obtained from the benthic foraminifera and ostracoda compositional data set. 
diversity peaks (at 181 and $133 \mathrm{~cm}, 6$ and 8 taxa respectively), despite a low general diversity (1-2 taxa). There is a gradual transition to OGA2 $(85-133 \mathrm{~cm})$, with the lowest occurrence of the most common species Normanicythere leioderma close to the basal sample, and the disappearance of 3 taxa in the topmost sample (Rabilimis mirabilis, Heterocyprideis sorbyana, Finmarchinella barentzovoensis). In OGA3 $(67-85 \mathrm{~cm})$ the average species richness is higher, due to the scattered occurrence of rare accessory taxa (e.g., Cytheropteron spp., Finmarchinella aff. finmarchica). The species Normanicythere leioderma and Elofsonella concinna are only present in this brief interval and disappear at the top of the unit.

A complete faunal turnover on species and to a large scale on generic level takes place in sample $67 \mathrm{~cm}$, with a marked increase in species richness from 2 to 6 taxa. OIA $1(55-67 \mathrm{~cm})$ is characterized by the stepwise establishment of the most common and long-ranging species (Cytherella spp., Krithe aquilonia, Neonesidea inflata, Pterygocythereis spp.). The succession of lowest occurrences however is markedly different from core POS 391 559/2, especially the presence of Muellerina abyssicola and Thaerocythere crenulata in the basal sample $67 \mathrm{~cm}$. In OIA2 accessory taxa (e.g., Bythocypris affinis, Argilloecia conoidea, Macrocypris sp., Cytheropteron spp.) appear in a rather scattered pattern, increasing the overall species richness to 5-10 taxa.

\subsection{Statistical treatment of the benthic foraminifera dataset}

Hierarchical clustering based on the Bray-Curties Similarity matrix (Figs. 4A and 5A) and nMDS (Figs. 4B and 5B) plots were applied on the data set of both cores (Appendices 3 and 4). Results obtained from this multivariate statistical treatment provide useful information about possible and discrete distribution patterns of foraminiferal assemblages in sediment cores, including the contribution (Appendices 1 and 2) of each single species to the total similarity (Clarke and Warwick, 1994). To simplify the interpretation (Appendices 1 and 2) and reduce the number of species with very low contributions without losing significant information, a cutoff value of the cumulative contribution was fixed at $90 \%$. A similarity cut is applied to the two cores at different similarity levels. This procedure is made according to the interpretation of the assemblages made with the abundance curves and with the lithology.

\subsubsection{Core POS $391559 / 2$}

The hierarchical cluster analysis on core POS 391 559/2 (Appendix 1) shows two clusters (FH1 and FH2) separated at $64 \%$ of the BrayCurties Similarity (Fig. 4A). Samples from the lower part of the core (226, 241, 256, 268, 271 and 277) belong to cluster FH1 whereas all the others belong to cluster FH2 (Fig. 4A). On the nMDS plot (Fig. 4B) this separation between cluster $\mathrm{FH} 1$ and $\mathrm{FH} 2$ is highlighted by a dashed line. At a lower level of similarity (72\%), three clusters can be recognized.

Cluster FH1 keeps unchanged (226, 241, 256, 268, 271 and 277). Thirty-four species account for $90.3 \%$ of the average similarity (Appendix 1). This assemblage is dominated by C. pachyderma and $A$. angulosa whereas $P$. subcarinata, $C$. ungerianus and $D$. coronata are major accessory species contributing at almost the same level (Appendix 1; Fig. 4). Cluster FH1 is exclusively found within lithological unit P-3. Cluster FH2 is further subdivided in cluster FH2A and FH2B. Cluster FH2B includes samples from the upper part of the core $(1,10,16,31,76,82$ and 91) where the IRD content is generally higher and species diversity lower (Fig. 6). Thirty-three species represent $90.6 \%$ of the average similarity (Appendix 1 ). In this Cluster Cibicidoides pachyderma gives the highest contribution to the assemblage followed by $D$. coronata and accessory species $A$. angulosa, C. ungerianus, C. teretis and C. reniforme (Appendix 1; Fig. 4).
The remaining samples belong to cluster FH2A mostly corresponding to lithological unit P-2 (except samples 25, 46 and 61). Thirty-nine species account for $90.4 \%$ to this assemblage (Appendix 1) dominated by $C$. pachyderma. Accessory species are A. angulosa, D. coronata, and C. ungerinaus.

\subsubsection{Core POS391 559/3}

The dendrogram and the nMDS plot resulting from the BrayCurties similarity matrix based on the dataset of core POS391 559/ 3 (Appendix 4) is given in Fig. 5. At lowest similarity (14\%) the hierarchical clustering separates two assemblages, FG1 and FG2 (Fig. 5A). The separation between those clusters is characterized by a dashed line on the nMDS plot (Fig. 5B). Cluster FG1 includes the samples from 70 to $282 \mathrm{~cm}$ exclusively found in lithological unit G (Fig. 3B). All other samples belong to cluster FG2 $(1-67 \mathrm{~cm})$ and correspond to the upper part of the core containing coral fragments. The cluster coincides with lithological units $\mathrm{P}$ and $\mathrm{T}$ (Fig. 3B).

By increasing the similarity (44\%), three assemblages (FG1A, FG1B and FG2) (Fig. 5A) are highlighted. This procedure allows to split cluster FG1 into cluster FG1A and FG1B. Samples from cluster FG1B consist of eight transitional samples found in dropstone layer L4 $(70-91 \mathrm{~cm})$ just below the coral facies (cluster FG2), two samples (133 and $136 \mathrm{~cm}$ ) from IRD layer L3 and three other samples $(106,121$ and $199 \mathrm{~cm})$ distributed along lithological unit G.

At $57 \%$ of Bray-Curties Similarity the dendrogram (Fig. 5A) displays five clusters (FG1A1, FG1A2, FG1B1, FG1B2 and FG2). At this level the dissimilarity between the clusters is lower but still in agreement with the SIMPROF test and thus clearly statistically significant. Furthermore, compared to the (dis-)similarity between clusters in core POS391 559/2 (Appendix 2; Fig. 4A), a value of 57\% similarity points out considerably larger differences. The nMDS plot (Fig. 5B) shows also the ordination of the samples using a low stress value of 0.06 and the affiliation to their respective assemblages.

The samples (187, 226-250 and 259-282 cm) belong to cluster FG1A1 and correspond to the lower part of the core (Figs. 5 and 7). All samples from cluster FG1A1 (except sample $187 \mathrm{~cm}$ ) represent almost continuously the lowest part of the glaciomarine sediments (G), except for sample $253 \mathrm{~cm}$ belonging to FG1A2 (Fig. 7). In this assemblage ten species contribute the $91.7 \%$ of the average similarity. Assemblage FG1A1 is dominated by C. reniforme and E. excavatum f. clavata. Elphidium incertum is considered as a major associated species (Appendix 4; Fig. 5). Cluster FG1A2 groups samples covering the largest part of lithological unit G (94-103, 109-118, 124-130, 139-196, 202-223 and $253 \mathrm{~cm}$ ). Thirteen species account for $90.2 \%$ of the average similarity. This assemblage is largely dominated by C. reniforme. Elphidium excavatum f. clavata is the major accessory species together with the less contributing species $N$. labradorica, C. ungerianus and E. incertum. In cluster FG1B1 are found samples preceding those from the coral facies (70-79), one sample (133) from the upper part of IRD layer L3 and sample $199 \mathrm{~cm}$ (Fig. 7). Fourteen species represent 90.3\% of the average similarity of this assemblage largely dominated by C. reniforme followed by the accessory species $N$. labradorica, C. pachyderma and $C$. ungerianus. Cluster FG1B2 includes samples from the lower part of IRD layer L4 (82-91) and L3 (136) as well as scattered samples from lithological unit G $(106$ and $121 \mathrm{~cm})$. Only twelve species account for up to $91.4 \%$ of the average similarity (Appendix 2). Cassidulina reniforme shows the highest contribution within this assemblage while E. excavatum f. clavata, E. incertum and $N$. labradorica are the principal accessory species. Cluster FG2 keeps unchanged at all the three (dis-)similarity levels and groups the samples (1-67) from the coral facies (Fig. 7). Thirty-one species account for $90.4 \%$ of the average similarity of this 
assemblage dominated by $C$. pachyderma (Appendix 2). Major accessory species of this assemblage are $C$. ungerianus, $A$. angulosa and D. coronata (Appendix 2; Fig. 5).

\subsection{Phosphorus}

In core POS391 559/3, the detrital phosphorus (P) is a dominating phosphorus phase that accounts for up to $54 \%$ of the total extracted phosphorus. Within lithological unit G, the detrital P displays high concentrations (3.5-18.3 $\mu$ moles P/g of sediment; Fig. 8C). In the lowermost part of the core $(226-282 \mathrm{~cm})$ detrital P shows rather constant values ranging from 13.5 to $16.5 \mu$ moles $\mathrm{P} / \mathrm{g}$ of sediment. In the interval of $70-223 \mathrm{~cm}$, the concentrations are fluctuating sensibly more with prominent negative peaks at $190 \mathrm{~cm}(8.7 \mu$ moles $\mathrm{P} / \mathrm{g})$, $175 \mathrm{~cm}(8.9 \mu$ moles $\mathrm{P} / \mathrm{g})$ and $145 \mathrm{~cm}(8.5 \mu$ moles $\mathrm{P} / \mathrm{g})$. A considerable drop in detrital P occurs from $82 \mathrm{~cm}(15.9 \mu$ moles $\mathrm{P} / \mathrm{g})$ and concentrations become extremely lower at $70 \mathrm{~cm}(3.5 \mu$ moles $\mathrm{P} / \mathrm{g})$ and $64 \mathrm{~cm}(5.4 \mu$ moles $\mathrm{P} / \mathrm{g})$. In lithological units $\mathrm{T}$ and $\mathrm{P}$, concentrations are relatively stable with values ranging from 7.2 to $10.8 \mu$ moles $\mathrm{P} / \mathrm{g}$ of sediment before decreasing slightly at the uppermost end of the core $(5.9 \mu$ moles $\mathrm{P} / \mathrm{g}$ at $4 \mathrm{~cm})$ (Fig. 8).

\section{Discussion}

The increasing knowledge (e.g., Murray, 1991, 2006) in the last $20 \mathrm{yr}$ about the ecological requirements of living benthic foraminifera has considerably improved the paleoenvironmental interpretation inferred from fossil assemblages. Detailed study of benthic foraminiferal assemblages may therefore provide a useful tool to reconstruct the evolution and transitions of large and small-scale paleoenvironmental and paleoclimatic changes.

Benthic foraminiferal assemblages of both cores record paleoceanographic changes from 15,300 to 2020 cal. yr BP, thus providing complementary information about the last deglaciation (e.g., Vorren and Plassen, 2002; Winsborrow et al., 2010, 2012) that coupled with the detrital phosphorus content give a first insights about the early cold-water coral colonization at Lopphavet. Ostracoda assemblages provide an additional approach to understand the transition from glacial to interglacial as well as the evolution of the coral reef during the Holocene.

\subsection{Sedimentary environment}

The relatively old ages obtained for the sediments at the top of core POS391 559/2 (2020 cal. yr BP) and POS391 559/3 (6800 cal. yr BP) may imply different sedimentary processes evolving in time on the Lopphavet reef. These old ages could be either related to erosion of former accumulated sediments, to depositional gaps, low sedimentation rates, increased current activity or to rework of older sediments. Both cores are characterized by a coarsening-upward cycle and increased occurrence of IRD, pointing to enhanced current activity and possibly remobilization of surrounding sediments. Since CWC usually thrive in high-energy environments, hiatuses or local reworking are not uncommon features (López Correa et al., 2012). For example, López Correa et al. (2012) postulated that in Stjernsund (Fig. 1), the 6000 ka gap occurring in the Holocene CWCs is linked to the onset of tidal currents across the fjord basin, causing enhanced erosion and preventing coral growth.

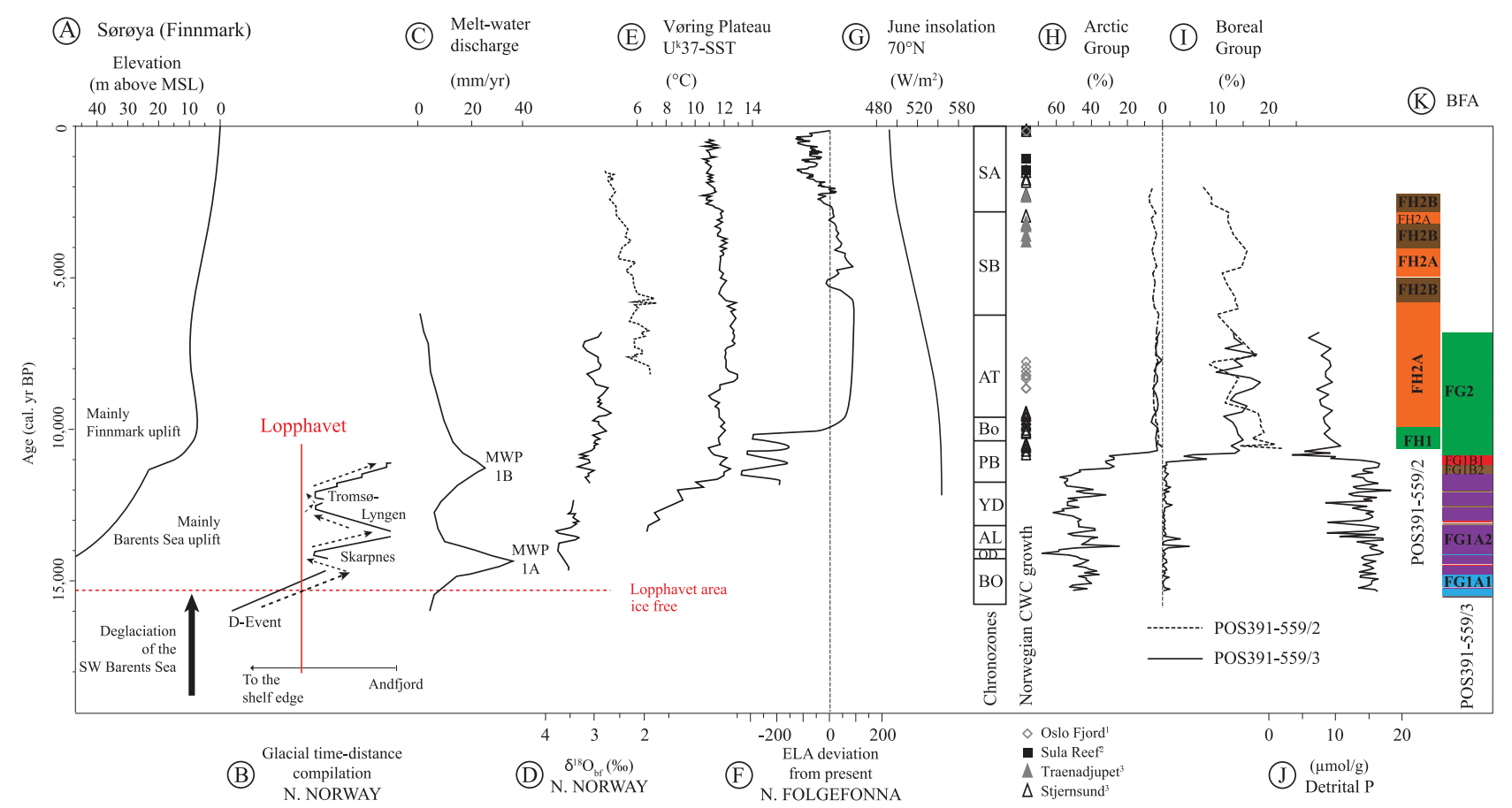

Fig. 8. Regional paleoproxys from Norway (A-G): (A) Mean sea-level reconstruction in the area of Sørøya (Finnmark) (modified after Romundset et al., 2011). (B) Ice position along the shelf in the region of Andoya (modified after Vorren and Plassen, 2002). Location of the Lopphavet cold-water coral reef is indicated by the solid red line. (C) Global rates of glacial melt-water release obtained from the Barbados sea-level curve with Meltwater Pulse (MWP) 1A and 1B (Fairbanks, 1989). (D) Stable oxygen isotopes from benthic foraminifera. Dashed curve show data from the Malangen fjord (Hald et al., 2003). Solid curve correspond to data from Ingødjupet (Aagaard-Sørensen et al., 2010). (E) $U_{37}^{K}$ Sea-surface temperature (SST) reconstruction from the Vøring Plateau (Calvo et al., 2002). (F) Glacier fluctuations reconstruction in northern Folgefonna (Bakke et al., 2005). The curve indicates the variations of the equilibrium-line altitude (ELA) relative to nowadays. (G) Summer insolation at northern latitudes (Berger and Loutre, 1991). All curves are calibrated to calendar years (AD 1950, left scale). Chronozones are according to Mangerud et al. (1974). The Norwegian CWC growth history is based on ${ }^{14} \mathrm{C}$ datings of corals from the Oslo fjord (Mikkelsen et al., 1982) and on U/Th from the Sula reef (Schröder-Ritzrau et al., 2005) and from Traenadjupet and Stjernsund (López Correa et al., 2012). (H) Displays the abundance (in \% of the total fauna) of arctic species (Cassidulina reniforme) and (I) boreal species (Angulogerina angulosa, Cassidulina laevigata, Melonis barleeanum and Uvigerina peregrina) in cores POS391 559/2 and POS391 559/3. (J) Detrital phosphorus record from the core POS391 559/3. (K) Benthic foraminiferal assemblages from cores POS391 559/2 and POS391 559/3. 
At the Fugloy reef on the open Norwegian shelf close to our site (Fig. 1), tidal-governed current velocities may reach $30 \mathrm{~cm} / \mathrm{s}$ on topographic highs colonized by living CWC at $120-160 \mathrm{~m}$ water depth and along channels at 178-192 m water depth (Lindberg et al., 2007). In this area, Lindberg and Mienert (2005) recovered a $50 \mathrm{~cm}$ long gravity core (JM01-1501; $70^{\circ} 22.5^{\prime} \mathrm{N}, 20^{\circ} 37.0^{\prime} \mathrm{E}$ at $223 \mathrm{~m}$ water depth) containing coral fragments and characterized by a clear fining-up in the upper $30 \mathrm{~cm}$ of the core. Since the U/Th dated coral fragments revealed inverted ages and since the closest observed reef is located at ca. $2 \mathrm{~km}$ from the core site, the authors interpreted this interval as a turbidity-flow deposit. They also identified typical diamicton deposits lacking Holocene sedimentation and showing a coarsening-up sequence from bottom to top. Vorren et al. (1987a, 1987b) attributed the gravel deposits from this area to strong winnowing of early Holocene glacial sediments.

The pebbly facies at the base of the CWC reef at Lopphavet (Fig. 2) are also interpreted as a result of winnowing and removal of the finest material (Freiwald et al., 2002). In core POS391 559/3, the pebbly facies, which includes the top of the IRD layer L4 and the lithological unit $\mathrm{T}$, can be linked to strong winnowing and condensation of glaciomarine sediments (Fig. 3B). The removal of the finest fraction and the subsequent apparent accumulation of interglacial sediments, therefore provide a possible explanation for the high occurrence of IRD within this interval (Fig. 3B). This hypothesis is also supported by the anomalous low values of detrital $P$ in the interval $61-84 \mathrm{~cm}$ (Fig. 8). Since the detrital P was measured on sediment grounded and sieved through a $<150$ um mesh sieve, the signal from the finest fraction, which was removed by currents may be missing. Hald and Vorren (1987a) observed that only one of the several cores they retrieved records the Late Weichselian glaciomarine sediments and that an unconformity was present in all the others.

Therefore, the old ages at the top of core POS391 559/3 may be linked to reduced sedimentation and/or sporadic erosional phases, as corroborated by the relatively low sedimentation rates and the thin coral-rich layer $(67 \mathrm{~cm})$. Several layers of coarser sediments in unit P may indicate the removal of the finest material in these layers with consequent condensation of sediments and benthic assemblage mixing (Fig. 3B). This process may be responsible of the unclear benthic foraminiferal signal obtained from the cluster analysis for the coral interval (Fig. 5). However, the almost total absence of typical arctic/subarctic species (e.g., $N$. labradorica, E. incertum, E. excavatum f. clavata) in this section excludes strong sediment rework with the underlying glaciomarine sediments. The topmost coarsening-up and IRD input in the uppermost part of core POS391 559/3 is therefore interpreted to be related to strong bottom currents sorting the sediments.

A similar coarsening-up and IRD input is observed also in core POS391 559/2 from the base of unit P-3. However, its correlation with the top of core POS391 559/3 thus corroborating the increasing current regime prevailing around the coral reef at this time cannot be proved. On the contrary the presence of a living CWC framework at core site POS391 559/2 may have increased the vertical accretion of the reef by trapping and baffling sediments (e.g., Freiwald et al., 2002; López Correa et al., 2012). As observed by Dorschel et al. (2007) living corals preferentially settle on the higher parts of mounds/reefs that are faced by strong current flow and that the coral thickets provide low-energy microenvironments protecting the finer sediments from resuspension. They suggested that an asymmetric flow pattern of bottom currents promotes a westward sediment movement consisting mainly of coarser fractions $(190-210 \mu \mathrm{m})$ clogging the living corals. Bioeroded dead coral framework may have allowed the erosion of the baffled sediments afterwards (Dorschel et al., 2007). Severe hydrographic changes may have triggered the decline of the corals present in core POS391 559/2, and/or their migration towards more suitable niches on the reef with consequent exposure of the dead coral framework to winnowing and erosion through currents. Therefore, the coral-rich layer POS391 559/2 probably coincides with another phase of coral growth with respect to POS391 559/3 (Fig. 3A).

In the coral-rich sequence of POS391 559/2 the typical glaciomarine benthic foraminiferal fauna is completely missing, rejecting the hypothesis of a major sediment remobilization from the glaciomarine record below. Only C. reniforme, a glaciomarinerelated species is consistently present in the coral-rich intervals of both cores, indicating that this species has a high potential to adapt to fluctuating water temperatures and salinity.

\subsection{The last glacial-interglacial transition: a major paleoclimatic and paleoceanographic shift}

Typical Atlantic-Boreal taxa (FG2) and Arctic-Subarctic glaciomarine taxa (FG1) cluster separately at the $86 \%$ of the Bray-Curtis Dissimilarity level in core POS391 559/3.

Benthic foraminiferal assemblage FG1 (Appendix 2; Fig. 5) is largely dominated by the species $A$. gallowayi, $C$. reniforme, E. excavatum f. clavata, E. incertum, $N$. labradorica usually reported from arctic and subarctic environments (Feyling-Hanssen, 1964; Corner et al., 1996; Hald and Korsun, 1997; Korsun and Hald, 1998; Polyak et al., 2000, 2002; Kubischta et al., 2010, 2011).

The dominant species (C. reniforme and E. excavatum f. clavata) of this assemblage contributes up to $90 \%$ to the total fauna (Fig. 3B) and have been reported from relatively shallow fjords of Svalbard close to glacier termini (Hansen and Knudsen, 1995; Hald and Korsun, 1997) and from glaciomarine clays off Nova Zemlya tidewater glaciers (Korsun and Hald, 1998). Both species generally thrive in slightly low salinity waters and may withstand bottom temperatures of $<-1{ }^{\circ} \mathrm{C}$ (Hald and Korsun, 1997; Polyak et al., 2002). In the late Quaternary glaciomarine records from the Barents Sea and the Kara Sea, Cassidulina reniforme and E. excavatum f. clavata represent the dominant taxa often associated to glacier proximal environments (Hald et al., 1994; Kubischta et al., 2011; Polyak et al., 2000). In both living and fossil assemblages, the $C$. reniforme-E. excavatum f. clavata dominance is associated to low benthic foraminifera diversity (Korsun and Hald, 2000; Zajaczkowski et al., 2010).

In some layer this assemblage is co-occurring together with abundant Boreal and Atlantic water-associated species indicating a distinct successions of paleoenvironmental changes as also proven by the fluctuations in benthic foraminiferal diversity (Figs. 3B and 7).

Nonionellina labradorica and E. incertum are known to occur in more stable environments with more saline waters than E. excavatum f. clavata and C. reniforme (Hansen and Knudsen, 1995). Nonionellina labradorica shows generally a positive correlation to water depth, whereas E. incertum typically settles on the shallower parts of high latitude shelves (Hansen and Knudsen, 1995; Hald and Korsun, 1997).

The transition from glaciomarine-dominated species to the Boreal fauna has been observed around at 10,900 cal. yr BP in the area of Ingoydjupet (Aagaard-Sørensen et al., 2010). Hald et al. (2003) report the transition from glaciomarine to normal open marine sedimentation around 10,300 cal. yr BP in the Malangen fjord. In Stjernsund, López Correa et al. (2012) dated the oldest CWC fragment at 10,900 cal. yr BP thus providing evidence for more suitable sea-bottom conditions for coral growth shortly after the Younger Dryas Termination. Hald and Aspeli (1997) document the establishment of bottom water conditions similar to Modern ones at about 10,000 yr BP (uncalibrated) from the upper continental slope of the northern Norwegian Sea (core T-88-2 and NP90-57; 1500 m water depth).

A study performed on 16 cores recovered from two troughs (455 and 505 m water depth; see Hald and Vorren, 1984, 1987a for core position) on the continental shelf off Troms, Hald and Vorren (1987a, 1987b) showed that in this area the benthic turnover took place at around $10,000 \mathrm{yr} \mathrm{BP}$ (uncalibrated). These authors also 
report bottom water temperatures similar to the present as early as $9700 \mathrm{yr} \mathrm{BP}$ (uncalibrated), based on oxygen isotopes. In the same area, Thomsen and Vorren (1986) noticed this major paleoceanographic shift and a turnover in the macrofauna (bivalves) also around ca. 10,000 yr BP (uncalibrated).

Further south, in the Skagerrak (core MD99-2286; $225 \mathrm{~m}$ water depth), this transition started at about 10,300 cal. yr BP with establishment of fully interglacial conditions around $9250 \mathrm{cal}$. yr BP (Erbs-Hansen et al., 2011).

The first occurrence of CWC fragments and the establishment of the highly diversified benthic foraminiferal assemblage of cluster FG2 occurring from $67 \mathrm{~cm}$ upward (Fig. 7) marks the transition from glaciomarine to fully interglacial conditions. The passage is also marked by a drastic decrease of all the typical glaciomarine species. This faunal turnover coincides with a major shift in diversity (SR and Fisher's alpha index).

The assemblage of cluster FG2 (Fig. 7; Appendix 4) is dominated by Boreal taxa such as $A$. angulosa, $D$. coronata, $C$. pachyderma, $C$. ungerianus and $M$. barleeanum characteristic of a relatively well oxygenated environment with strong current activity and warmer and normal saline (Atlantic) water masses (Fig. 8). Similar modern (stained+dead) assemblages are reported from Norwegian cold-water coral reefs (Stjernsund, Rost, Sula and Korallen reef) and are referred to well oxygenated environments with strong bottom currents and abundant input of fresh phytodetritus (Spezzaferri et al., 2013). Living (stained) benthic foraminifera from CWC reefs also show assemblages similar to those of FG2 and in situ measurements indicate that they thrive in water temperatures of about $6.4{ }^{\circ} \mathrm{C}$ and salinities of 34.94 (Rüggeberg et al., 2011; Spezzaferri et al., 2013). All the dominant species of FG2 show distinct zonal distributions according to water depth, current activity, sediment grain size, oxygen and organic carbon availability, salinity and water temperature in the Norwegian and North Sea (Sejrup et al., 1981; Corliss and Chen, 1988; Klitgaard-Kristensen et al., 2002). The high abundances of M. barleeanum, Epistominella exigua and Epistominella vitrea confirm higher productivity surface waters and increased export of fresh phytodetritus to the sea-floor (Corliss and Chen, 1988; Hald and Steinsund, 1992; Murray 2006) necessary for corals to grow.

The species Discanomalina coronata seems to have restricted habitats. Margreth et al. (2009) argued that this species is closely linked to specialized micro-habitats of CWC reefs and may therefore represent a possible bioindicator for active CWC reefs. The distribution of $D$. coronata in our cores is confined to coral fragments-rich intervals and thus in accordance with this hypothesis. The relatively large differences in benthic foraminiferal diversity between on and off-reef facies on the Norwegian CWC reefs mentioned by Spezzaferri et al. (2013) provide additional evidence for increased and specialized (micro)-habitats availability on reef for the benthic foraminifera.

The increased and consistent occurrence of radiolarians and planktonic foraminifera in the Holocene highlights the transition to Modern oceanographic conditions also in the upper water column (Fig. 7). The shift in the planktonic fauna (foraminifera and radiolarians) is contemporary to the benthic turnover thus indicating a paleoceanographic change extended to the entire water column and possibly related to climate warming. This assumption is corroborated by the gentle decreased amount of detrital phosphorus in units $\mathrm{T}$ and $\mathrm{P}$ from $61 \mathrm{~cm}$ upward (about $50 \%$ lower than in glaciomarine sediments) indicating reduced detrital flux from erosion on the mainland (Fig. 8) and possibly relatively stable climatic conditions in Northern Norway at least until 6800 cal. yr BP (Fig. 8).

However, Erbs-Hansen et al. (2011) observed that the sediments spanning the interval from 10,300 to $9250 \mathrm{cal}$. yr BP contained abundant Arctic and polar benthic foraminifera (e.g., E. excavatum $\mathrm{f}$. clavata, N. labradorica). Their presence provided evidence for the persisting of cold-bottom water masses resulting from the earlier strong stratification due to the glacial meltwater from the Baltic Sea (Erbs-Hansen et al., 2011). They interpreted this interval as a transitional phase.

The paleoceanographic signal inferred from the benthic foraminifera fauna from our two cores clearly shows the establishment of conditions similar to the Present along the Lopphavet reef at about 10,725 cal. yr BP (along the flanks) and 10,600 cal. yr BP (on its top), respectively.

Since these ages slightly coincides with the transition between units G/T in POS391 559/3 or with the near-base of core POS391 $559 / 2$, they may not represent the real transition of glaciomarine to interglacial sedimentation and the base of the coral reef, respectively, that may be slightly older.

Furthermore, the shift from Arctic to Boreal in benthic foraminiferal assemblages from $79 \mathrm{~cm}$ upward in core POS391 559/3, indicates that bottom water warming at Lopphavet started in this interval (Fig. 8). This shift is also supported by the increasing diversity of benthic foraminifera and ostracoda, a larger number of benthic foraminifera per gram of sediment and the progressive increasing abundance of biogenic components (Fig. 3b). Planktonic foraminifera are present from $67 \mathrm{~cm}$ upward indicating the possible persisting meltwater discharges from the Hinterland until 10,725 cal. yr BP. Accordingly we suggest that the onset of CWC growth in Lopphavet took place earlier than $10,725 \mathrm{cal}$. yr BP. The reported early interglacial conditions prevailing off Troms by Hald and Vorren (1987a, 1987b) and Thomsen and Vorren (1986) shortly after the Younger Dryas Termination (ca. 10,000 yr BP uncalibrated) clearly points to differences in the spatial distribution of Atlantic water masses on the Norwegian shelf, probably controlled by the sea-floor topography and first affecting the outer part of the shelf and the connections with deep troughs. Furthermore, the relatively large differences in the timing of the establishment of modern interglacial conditions on the Norwegian sea-floor, suggests that warming produced by the Atlantic water in flow may have started earlier on the northern continental shelf (Hald et al., 2003).

\subsection{Deglaciation of Lopphavet area}

Reducing the Bray-Curtis Dissimilarity level to e.g., $44 \%$ and $57 \%$ further subdivisions within Cluster FG1, corresponding to deglaciation episodes at centennial-millennial-scale can be identified in about $4550 \mathrm{yr}$ (Fig. 5). These episodes are accompanied by changes in diversity of benthic and planktonic foraminifera, ostracoda assemblages, biogenic components and grain size distribution within FG1 (Figs. 3B and 5). Distribution patterns observed in similar late Pleistocene-Holocene assemblages from the Norwegian and Barents Sea (e.g., Hald and Vorren, 1987a, Aagaard-Sørensen et al., 2010) as well as other paleoclimatic proxies (e.g., phosphorus, insolation, oxygen isotopes; Fig. 8) refer to a complex deglaciation model constrained by unstable climatic conditions as described here below.

\subsubsection{Semi-open marine environment with periodic sea-ice cover} and highly fluctuating water salinity (assemblage FG1A1)

The assemblage of cluster FG1A1 is observed from dropstone layer L1 and the finest grain sized lithology observed in core POS391 559/3 up to around $220 \mathrm{~cm}$. The sediments are barren of planktonic foraminifera and radiolarians (Fig. 7). Since no evidence of dissolution is observed, the absence of planktonic fauna suggests unsuitable living conditions for these organisms possibly resulting from permanent sea-ice cover or glacial meltwater release from the recessing ice-sheet. The lowest diversity of benthic 
foraminifera, rarity of ostracoda and other biogenic components also indicate a relatively unsuitable benthic environment at this time.

Benthic foraminiferal assemblage are dominated by C. reniforme and E. excavatum f. clavata, which are known to occur in glacier-proximal settings (Hald and Korsun, 1997). Korsun and Hald (2000) showed that E. excavatum f. clavata dominates closest to the Tempelfjorden (Svalbard), glacier terminus whereas C. reniforme becomes leading further down the fjord basin.

Korsun and Hald (1998) suggest the increased export of fresh phytodetritus to the sea-floor resulting from lower meltwater release as a possible trigger for the proliferation of $C$. reniforme further distal to the glacial meltwater source. The more opportunistic species E. excavatum f. clavata on the contrary seems to take advantage of melt water and/or river discharge (e.g., Jennings et al., 2000; Murray, 2006; Kubischta et al., 2010; Grøsfjeld et al., 2006; Polyak et al., 2002; Hald et al., 1994), or to periodic sea-ice cover (e.g., Hald et al., 1994).

Elphidium incertum, another important component of assemblage FG1A1 is known from shallow water settings connected to the open ocean. It has also been described as related to increased sea-ice covers in the Barents Sea (Polyak and Mikhailov, 1996) and in the Kara Sea (Polyak et al., 2000) or associated to seawater salinity fluctuations (Polyak et al., 2002).

These three species account for up to $90 \%$ of the total fauna (Appendix 2) in the interval $226-280 \mathrm{~cm}$ and thus the assemblage can be interpreted to represent a cold, glacier-proximal and relatively shallow environment probably affected by low seawater salinity.

The accompanying species $N$. labradorica, widely occurring in glaciomarine sediments, is rare within FG1A1 (Appendix 2). This species has been associated to glacier proximal conditions on the Northern Norwegian shelf (Hald and Vorren, 1987a,b) but it does not tolerate low salinities (Hald and Korsun, 1997; Cedhagen, 1991). The opportunistic species Stainforthia loeblichi present in assemblage FG1A1 was also found in connection with sea ice (Steinsund, 1994).

Nevertheless, the presence of boreal species (e.g., M. barleeanum, C. pachyderma and C. ungerianus) within FG1A1 clearly demonstrates that at this time the Lopphavet had already connections to warmer and more saline water masses. Especially the presence of the Atlantic species Cassidulina laevigata in the uppermost samples of FG1A1 implies its immigration along the Norwegian coasts following the inflows of Atlantic water masses (Klitgaard-Kristensen et al., 2002). Analog is the occurrence of Cassidulina teretis, which has a widespread distribution in the Barents and Kara seas but only in areas bathed by Atlantic waters (Lubinski et al., 2001). Mackensen and Hald (1988) showed that C. teretis thrives on the Norwegian continental slope in waters of $-1{ }^{\circ} \mathrm{C}$ and salinities about $34.92 \%$. However, they also document this species in glaciomarine upper Weichselian sediments.

Hald and Vorren (1987a) studied 8 gravity cores form the Malangsdjupet and the Andfjorden. They report the dominance of E. excavatum f. clavata and C. reniforme (zone 4) during the glacial re-advance of the D-Event and their replacement after 13,000 yr BP (uncalibrated) by a more diversified C. reniforme- $N$. labradoricum (zone 3 ) assemblage. They interpreted assemblage of zone 4 as a cold glaciomarine setting with reduced salinity and oxygen depleted bottom waters. Our assemblage FG1A1 yields a transitional faunal composition compared to their zone 3 and 4 assemblages.

Accordingly, we suggest that assemblage FG1A1 refers to an arctic shelf environment, glacier proximal with periodically extended sea-ice cover and under seasonal influence of turbid glacial meltwater leading to rather instable water salinity. Alternation of (sea-)ice rafting is frequent during this period (Vorren and Plassen, 2002). The FG1A1 assemblage refers in time to the end of the glacial re-advance of the D-Event. The fine-grained sediment matrix and the low abundances of epibenthic foraminifera point to a rather low energy environment at Lopphavet with incursions of Atlantic water masses probably due to increased paleodepth (Fig. 8).

Furthermore, species E. excavatum f. clavata, E. incertum, N. labradorica, Fursenkoina complanata, P. bulloides and P. subcarinata have been described in many studies as tolerant to oxygen deficient environments (e.g., Gustafsson and Nordberg, 1999; Murray, 2006; Kaiho, 1994) which may indicate the presence of relatively stagnant waters depleted in dissolved oxygen.

\subsubsection{Influence of Atlantic waters under a sea-ice cover free} environment (assemblage FG1A2)

A strong decrease in abundance of $E$. excavatum f. clavata and $E$. incertum and a considerable increase in abundance of $C$. pachyderma, C. ungerianus, C. teretis and N. labradorica occurs in cluster FG1A2, with respect to cluster FG1A1 (Appendix 2). Assemblage FG1A2 is dominated by $C$. reniforme accompanied by E. excavatum f. clavata and $N$. labradorica. However, it is characterized by higher benthic foraminifera diversity (up to 31 species), higher ostracoda diversity (up to 9 species) and planktonic foraminifera in all samples except 160, 163, 202, 211, 214, 220 and 223 (Fig. 7). We suggest that the area was mostly ice-free and exposed to more favorable conditions for these organisms. Elphidium excavatum $f$. clavata and $E$. incertum are still present and significantly contribute to assemblage FG1A2 (Appendix 2; Fig. 7) indicating a cold environment prone to salinity fluctuations at the sea-floor and meltwater/glacial influenced conditions at surface waters. Both species are less common than in assemblage FG1A1, suggesting the presence of calving glaciers close to the fjord heads. Similar benthic foraminiferal taxa including species Astrononion gallowayi have also been reported from areas close to calving glaciers around Spitsbergen (e.g., Feyling-Hanssen, 1964; Elverhøi et al., 1980). Its presence in assemblage FG1A2 corroborate the interpretation.

Hald and Vorren (1987a, 1987b) showed that at Malangsdjupet and Andfjorden ecological conditions shifted at around 13,000 yr BP (after the D-event) from an E. excavatum f. clavata (zone 4) dominated assemblage to a more diversified $C$. reniforme-Nonion labradoricum (zone 3) dominated assemblage. Cibicides lobatulus (here Lobatula lobatula), E. excavatum f. clavata, C. teretis and Nonion barleeanum (here $M$. barleeanum) are accessory species (Hald and Vorren, 1987b). This assemblage persisted until 10,000 yr BP (uncalibrated) and was mainly attributed to early ingression of Atlantic water and/or to reduced glacial influence on the shelf waters leading to increased water temperatures and salinity, dissolved oxygen content and current activity. Although there are discrepancies in dating due to reservoir age and non-calibration of ages, the assemblage of zone 3 corresponds in time to most part of our glaciomarine record. However, Hald and Vorren (1987a, 1987b) associate the lower part of assemblage zone 3 (ca. 11,000$13,000 \mathrm{yr}$ BP) to warmer ecological sea-floor conditions and the upper part to the cooling following the Younger Dryas stage, but they do not refer to a clear subdivision into two distinct assemblages. A possible explanation for this difference could be the deeper water depth of the core sites off Troms and their location in troughs directly connected to the outer shelf. Thus, these benthic environments take advantage of more efficient inflow of warmer and more saline water of the NwAc and/or are less influenced by surface water conditions than the Lopphavet reef. Hald and Vorren (1987a) noticed also that $C$. reniforme and C. laevigata are more abundant towards the deeper part of the Andfjorden indicating more stable salinity and warmer bottom temperatures. According to the mean sea-level reconstructions for the area of Soroya 
(Finnmark) from Romundset et al. (2011), the Lopphavet reef thrived in deeper waters (ca. $+45-50 \mathrm{~m}$ water depth) at around 15,000 cal. yr BP and experienced an almost gradual shallowing-up until the present due to the isostatic uplift of the Barents Sea seafloor and of Finnmark (Fig. 8). In Stjernsund, López Correa et al. (2012) and Joseph et al. (2013) link the cooling of bottom water temperatures during the late Holocene to reduced Atlantic water inflow in the fjord resulting from the isostatic uplift of Fennoscandia.

However, Melonis barleeanum is usually reported in warmer waters of the NAC and associated to areas of high productivity in the Barents Sea (Koç et al., 2002; Mackensen et al., 1985), whereas, Cassidulina laevigata has been associated to Atlantic water in the North Sea (Klitgaard-Kristensen et al., 2002; Klitgaard-Kristensen and Sejrup, 1996), in the Barents Sea (Østby and Nagy, 1982) and from the FaroeShetland Gateway (Rasmussen et al., 2002).

Hald and Steinsund (1992) observed a strong positive correlation of C. laevigata with summer bottom temperature in the southwestern Barents Sea. Based on this observations and on the overall lower values of detrital phosphorus (Fig. 8), testifying reduce weathering on land, we suggest that the period corresponding to assemblage FG1A2 was characterized by more stable oceanographic conditions at Lopphavet with a decreasing of glacial related features (e.g., sea-ice cover, turbidity, ice-rafting) with consequent inflows of Atlantic waters. Episodic weathering and/ or eolian input may account for increased periodic detrital $P$.

More favorable conditions for living organisms at this time is also suggested by the occurrence of radiolarians, echinoderm fragments (sea urchin spicules and ophiurid ossicles), siliceous sponge spicules and marine molluscs (Fig. 3b). Furthermore, more diversified benthic foraminifera assemblages including boreal species such as $C$. crassa, $M$. barleeanum and the higher abundances of the epibenthic species C. ungerianus and C. pachyderma (Figs. $3 \mathrm{~b}$ and 8) point to the onset of the NwAC in this area with increasing current activity. From a local high abundance of $N$. labradoricum and the post-glacial immigration of $N$. barleeanum at around $12,400 \mathrm{yr} \mathrm{BP}$ (uncalibrated) in the Malangen Fjord, Hald and Vorren (1987a) infer a stronger influence of NwAC waters. Higher abundances of $C$. lobatulus were interpreted as a high-energy environment at the sea-floor.

Two major ice-rafting events (L2 and L3) are characterized by different assemblages compared to FG1A2 (Fig. 7). An assemblage FG1A1 colonized the dropstone layer L2 (Fig. 7), which can be related to a cooling at the sea-floor bottom due to a more proximal location of the ice-front. This layer may be linked to the end of the Skarpnes-Event producing large glacial meltwater release and preventing the ventilation of the bottom water masses.

\subsubsection{Intensive ice-rafting, meltwater release vs. enhanced $N A C$ activity (assemblages FG1B1 and FG1B2)}

The dropstone layer L3 is related to the second largest icerafting event recorded in the core (Fig. 3b). Assemblages FG1B1 at $133 \mathrm{~cm}$ and FG1B2 at $136 \mathrm{~cm}$ are associated to this layer (Fig. 5). Both assemblages characterize also dropstone layer L4 with FG1B2 at its base and FG1B1 at its top. Assemblage FG1B2 is characterized by high abundances of the arctic species $E$. excavatum f. clavata, E. incertum, C. reniforme, S. loeblichi (Fig. 3b, Appendix 2). The boreal and Atlantic species M. barleeanum, N. labradorica, C. laevigata, A. angulosa, C. ungerianus, C. aravaensis, C. pachyderma, F. wuellerstorfi and Epistominella vitrea are more abundant in assemblage FG1B1(Appendix 2).

Moreover, assemblage FG1B1 shows clearly higher benthic foraminifera diversity than assemblage FG1A1, FG1A2 and FG1B1 (Figs. 3b and 5) and contains more biogenic components (radiolarians, sponge spicules, marine shells, sea urchin spicules and ophiurid ossciles) (Fig. 3b).
Assemblage FG1B1 is very similar to the zone 3 assemblage of Hald and Vorren, 1987a, and is dominated by C. renifrome$N$. labradorica with major accessory species $E$. excavatum f. clavata, $M$. barleeanum and epibenthic species L. lobatula, C. ungerianus and C. pachyderma. It may indicate higher bottom water temperatures, relatively stable and normal marine salinity, higher current velocities and well oxygenated water masses.

The absence of an assemblage similar to FG1B2 in Malangsdjupet and Andfjorden suggests that Lopphavet (1) experienced less intensive Atlantic water intrusion than Malangsdjupet and Andfjorden during the Late Pleistocene/Early Holocene and (2) it was strongly and continuously influenced by climatic variability through a direct connection to the sub- and surface waters.

Hald and Vorren (1987b) noticed that the increased biogenic productivity due to the intensification of the Atlantic water influence and highlighted by the negative peaks in their $\delta^{13} \mathrm{C}$ isotope record at $11,200 \mathrm{yr} \mathrm{BP}$ corresponds to more abundant foraminifera (Hald and Vorren, 1987a). All layers characterized by assemblage FG1B1 (Fig. 7) may be related to similar high biogenic productivity triggered by enhanced influence of Atlantic waters.

The topmost FG1B1 assemblage occurring in core POS391 559/3 underlying the fully interglacial FG2 assemblage can be considered as the beginning of the onset of the modern NwAC. This assumption is also supported by the increasing abundance of the epibenthic species F. wuellerstorfi, which is often associated to increased bottom current activity and/or deepening (Margreth et al., 2009), to bottom water ventilation (Linke and Lutze, 1993; Struck, 1995) and lateral advection of organic material to the seafloor (Lutze and Thiel, 1989).

Similar observations have been reported for M. barleeanum, which shows a positive correlation to depth in the Barents Sea (Østby and Nagy, 1982) and to generally increased organic carbon fluxes in the deep-sea (Loubere, 1996). Nees et al. (1997) showed that the Melonis group (M. barleeanum and M. pompiloides) correlates to high organic carbon content in the sediments of the Norwegian-Greenland Seas resulting from the high productivity event after the ice-retreat of the last deglaciation. Mackensen et al. (1985) suggest that the distribution of M. barleeanum is mainly controlled by fine-grained sediment (pelite) in the southern Norwegian Sea, however, this relation is not obvious in our record. We link therefore the occurrence of this species rather to nutrient enrichment of the water masses.

Higher abundances of $N$. labradorica have also been interpreted as signal for increasing nutrient availability in shallow arctic settings (Korsun and Hald, 1998). Aagaard-Sørensen et al. (2010) reported from Ingoydjupet Marine Organic Matter (MOM) values similar to the present SW Barents Sea conditions from ca. 11,500 cal. yr BP. They noticed that this increase coincides with higher abundances of $M$. barleeanum and postulated enhanced nutrient delivery to the sea-floor and permanent influence of Atlantic water. From 11,500 cal. yr BP to the fully interglacial conditions reached at about 10,900 cal. yr BP, the dominating benthic foraminifera in Ingoydjupet are $E$. excavatum $f$. clavata, M. barleeanum, C. reniforme, Cibicides spp. and C. neoteretis (here as C. teretis) with a marked increase in diversity (Aagaard-Sørensen et al., 2010).

The consistent timing (between 11,500 and $10,900 \mathrm{cal}$. yr BP) attributed to the establishment of the modern benthic foraminiferal fauna similar to our assemblage FG1B1 at Ingoydjupet and Lopphavet, suggest that the onset of the modern NwAC in Lopphavet can be tentatively placed slightly after the boundary between the Younger Dryas and the Preboreal stages. The Younger Dryas stage, was characterized at these latitudes by a cooling of the surface waters and low foraminiferal content in the sediments (Hald and Aspeli, 1997). 
Two meltwater events, termed as Meltwater Pulse 1A (MWP 1A) and MWP 1B (Fairbanks et al., 1992), reached their maximum during the Bølling period and at the end of the Younger Dryas respectively (Fairbanks, 1989).

It has been intensively discussed (e.g., Fairbanks, 1989; Lehman and Keigwin, 1992; Keigwin et al., 1991) that the decrease of salinity in the North Atlantic derived from the older meltwater discharge may have triggered oceanographic changes that lead to the cold Younger Dryas stadial (Broecker et al., 1988; Lambeck et al., 2002). The younger meltwater discharge at the end of the YD released from the vanishing Fennoscandian Ice Sheets, is probably responsible for the development of assemblage FG1B2A within IRD layer L4 and has produced a short-term cooling in the North seas, termed as "Preboreal oscillation" (Hald and Hagen, 1998).

Within this assemblage the high contribution of elphidae points to a glacial-influenced environment on the Lopphavet shelf. The absence of planktonic foraminifera in this section may imply seasonal sea ice-cover and/or water masses with sensibly lowered salinity (Steinsund, 1994).

The periodic presence of sea-ice is also supported by high abundance of S. loeblichi as reported by Steinsund (1994). Two level with high abundances of E. excavatum f. clavata have been reported by Hald and Vorren (1987a) at 11,100 and 10,500 yr BP (uncalibrated) off Troms in addition to fluctuating abundances of other species (e.g., L. lobatula, N. labradorica, C. teretis) and a low number of benthic foraminifera per gram of sediment. These features were attributed to the colder and unstable benthic environment of the Younger Dryas. Hald and Vorren (1987a) also concluded that the faunal composition and the dominating species were similar to the assemblage of zone 4 characteristic to the D-Event. Assemblage FG1B2 is similar to FG1A1 in faunal composition and diversity. However assemblage FG1B2 occurs only sporadically within assemblages FG1B1 and FG1A2, pointing to relatively short-termed instable environmental changes during the cold Younger Dryas. Furthermore, assemblage FG1B2 coincides with the deposition of IRD layer L3 and L4, which may rather suggest deglaciation with calving glaciers in the fjords leading to ice-rafting and glacial meltwater release.

We suggest therefore, that the occurrence of assemblage FG1B2 is controlled by intensive iceberg discharges from the unstable and active tidewater-glaciers (López Correa et al. (2012); Vorren and Plassen, 2002) leading to local stratification of the water masses due to the large turbid meltwater influx. This stratification may have also prevented the ventilation of the deeper water masses periodically promoting the proliferation of the more opportunistic species. The last occurrence of this assemblage in core POS391 $559 / 3$, coinciding with IRD layer L4 may then correlate with the end of the Younger Dryas, which was more unstable than its lower part due to the northward drift of the westerly winds and maximum summer insolation at $70^{\circ} \mathrm{N}$ (Berger and Loutre, 1991; Bakke et al., 2009) (Fig. 8).

Hald et al. (2007) showed that the transition from the YD to the Preboreal stage at the $60^{\circ}-77^{\circ} \mathrm{N}$ was marked by an abrupt warming at the surface waters with a temperature gradient close to $0{ }^{\circ} \mathrm{C}$ at $12,000 \mathrm{cal}$. yr BP and $10{ }^{\circ} \mathrm{C}$ at $11,000 \mathrm{cal}$. yr BP They showed that this warming was more gradual in the Barents Sea than in the North Sea due to remnant cold glacial meltwater at high latitudes. Sea-surface temperature reconstructions based on alkenones revealed temperatures of about $9{ }^{\circ} \mathrm{C}$ at $12,000 \mathrm{cal}$. yr BP rising to $12{ }^{\circ} \mathrm{C}$ at ca. $11,000 \mathrm{cal}$. yr BP on the Voring Plateau (Calvo et al., 2002). Hald et al. (2003) report increasing sea-bottom water temperatures starting from 11,800 cal. yr BP and warming of surface waters ca. $200 \mathrm{yr}$ later due to the remaining cold glacial meltwater at the Malangen fjord.
Short fluctuations from assemblage FG1A2 to FGB2 are therefore, more likely to be interpreted as occurring during short-termed ice rafting events and/or seasonal sea-ice formation/disintegration leading to highly fluctuating water salinity during the YD.

\subsection{The development of the CWC reef and the Holocene record}

Core POS391 559/2 shows a continuous sedimentary sequence from 2020 down to 10,600 cal. yr BP. Although the statistical treatment separates three different benthic foraminiferal assemblages throughout the core, they are characterized by a relatively similar composition pointing either to relatively stable oceanographic conditions and/or to moderate sensitivity to the climate forcing in Lopphavet during the Holocene. All these assemblages show a faunal composition similar to those from recent/subrecent CWC reefs on the Norwegian margin/shelf/fjords (Spezzaferri et al., 2013), CWC mounds in the Porcupine Seabight (Rüggeberg et al., 2005, 2007; Margreth et al., 2009; Schönfeld et al., 2011) and CWC ecosystems from mud volcanoes in the Alboran Sea (Margreth et al., 2011).

Assemblage FH1 occurring in Unit P1, differs mainly from the overlying assemblages by the co-dominance of $C$. pachyderma with the infaunal $A$. angulosa and high abundances of other infaunal species as P. subcarinata, M. barleeanum, Epistominella exigua and Bolivina pesudoplicata. The small infaunal species A. angulosa is often associated to high-energy environments (Mackensen et al., 1985; Schönfeld, 2002). Along the Irish Margin, this species is abundant within the dead coral facies, consisting mainly of coral rubble and fine-grained sediments (Margreth et al., 2009).

Abundant $M$. barleeanum suggests nutrient rich bottom waters in this interval (Caralp, 1989) as also supported by high abundances of the infaunal species $P$. subcarinata, B. pseudoplicata associated to high carbon flux rates (Murray, 2006; Corliss and Chen, 1988; Mackensen et al., 1995). Thomas et al. (1995) showed that the opportunistic species E. exigua in the Northern Atlantic becomes more abundant during spring plankton blooms increasing fresh phytodetritus supply to the sea-floor. Hald and Vorren (1987b) showed that between 9890 and 10,600 cal. yr BP, when assemblage $\mathrm{FH} 1$ is observed, the decreasing $\delta^{13} \mathrm{C}$ (benthic) values off Troms indicate a constant rise in primary productivity with an absolute maximum reached at $8000 \mathrm{yr}$ BP (uncalibrated). They suggest also that the increasing nutrient supply was related to the strengthening of the NCC.

Aagaard-Sørensen et al. (2010) suggested that at Ingoydjupet high ${ }^{12} \mathrm{C}$-enriched organic material was delivered to the sea-floor between 9300 and 10,900 cal. yr BP, based on planktonic and benthic $\delta^{13} C$ isotopes, high abundances of $M$. barleeanum and high MOM. Both, subsurface and bottom water masses were influenced by Atlantic water. They also noticed an increase in abundance in planktonic species Globigerinita uvula between 7500-9300 cal. yr BP. This species is generally related to decreasing water salinities and therefore, its dominance is interpreted as a widening of the NCC.

Therefore, we interpret assemblage FH1 as recorder for a strong influence of Atlantic water at Lopphavet with high nutrient supply to the sea-floor, relatively strong bottom currents and well oxygenated water masses at the sea-floor. The lowest abundances of the arctic species C. reniforme within this assemblage point to relatively warm bottom water temperatures, possibly the warmest during the whole Holocene record (Fig. 8). The transition at $9890 \mathrm{cal}$. yr BP to the most diversified assemblage FH2A may indicate the most favorable conditions for the benthic and planktonic fauna, with rather stable sea surface temperatures and bottom water temperatures, stable salinity and highest productivity waters as suggested by Knies (2005). The higher diversity of the benthic foraminifera (Fishers' alpha index) in 
FH2A is also explained by the occurrence of coral framework in this section.

The period between 5000 and 9300 cal. yr BP is characterized at Stjernsund, by bottom water temperatures of about $4-7{ }^{\circ} \mathrm{C}$, strong influence of the Atlantic water masses and high organic carbon fluxes to the sea-floor (Joseph et al. 2013). In this fjord, the planktonic foraminifera are scarce, possibly because of lowered sub-surface water salinity (Joseph et al., 2013).

Assemblage FH2A occurring in the coarsening-upward sediments in lithological unit P-2 (Fig. 3A) is characterized by higher abundances of epibenthic and lower abundances of infaunal species than assemblage FH1 (Fig. 6). The epibenthic assemblages consisting of $C$. pachyderma, D. coronata and $C$. ungerianus may indicate stronger bottom current activity (Margreth et al., 2009; Schönfeld, 2002). Infaunal species include A. angulogerina, M. barleeanum, $P$. subcarinata, B. pseuoplicata. A possible explanation for this faunal difference may be the difference in grain size. In particular coarse sediments are less suitable for infaunal species (Mackensen et al., 1995; Murray, 2006; Margreth et al., 2009). Coral framework/rubble is more suitable for epibenthic fauna (Margreth et al., 2009, Spezzaferri et al., 2013). The presence of Uvigerina peregrina in assemblage $\mathrm{FH} 2 \mathrm{~A}$ and $\mathrm{FH} 2 \mathrm{~B}$ only, may be explained by the requirement of this species in term of high quantity of labile organic matter and muddy to silty sediments (Schönfeld and Altenbach, 2005).

Margreth et al. (2009) and Schönfeld et al. (2011) showed that Uvigerina mediterranea is more likely to be found off-mound in the Porcupine Seabight but may also take advantage of fine-grained and organic matter rich sediments baffled by the coral thickets. The higher abundances of other infaunal species as Bolivina alata (Margreth et al., 2009) in this microhabitat and the high values of the benthic foraminifera Fisher's alpha index within the coral framework sections may confirm this hypothesis.

However the increasing upward abundances of the cold-water species $C$. reniforme and $C$. teretis in this assemblage refers to colder bottom water masses. Therefore, an increased influenced of the NCC on assemblage FH2A cannot be ruled out due to its shallower water depth and closer proximity to the shoreline.

Nevertheless, this cooling trend of the bottom water masses at Lopphavet intensifies upward with $C$. reniforme and $C$. teretis becoming remarkably more abundant in assemblage $\mathrm{FH} 2 \mathrm{~B}$, which is also characterized by a gradual decrease in boreal species diversity (Fig. 8). The general cooling at the sea-floor is also corroborated by the decreasing upward abundances of $C$. laevigata.

Furthermore, our data point to lower amounts of nutrients and probably also lower quality organic matter at the sea-floor, which may be related to either decreasing primary production in surface water related to cooler and less saline coastal waters and/or to lower input of organic matter due to the weakening of the NAC in this area. Decreased quantity and quality of the organic matter flux to the sediment is also underlined by the rather strong decreases of $M$. barleeanum, B. alata, P. subcarinata and U. peregrina (Murray, 2006). Spezzaferri et al. (2013) showed that in the Skagerrak the low abundance of labile organic matter usable for the CWC has probably lead to the decline of these organisms during the Holocene.

Lower abundances of $E$. exigua and $E$. vitrea in this assemblage corroborates the assumption of minor influx of phytodetritus to the sea-floor, but may also suggest increased current activity (Murray, 2006; Mackensen et al., 1995).

Stronger currents on reefs are supported by higher abundances of $D$. coronata and C. pachyderma within assemblage $\mathrm{FH} 2 \mathrm{~B}$ and the coarser lithology in unit P-1 (Fig. 3b). The coarsening-up in this section may be a limiting factor for the distribution of some infaunal species preferring muddy sediments. However, some opportunistic infaunal species like Nuttalides decorata, Eggerella humboldti, Nonionella iridea and the oligotrophic species $G$. subglobosa characterize the upper coarser part of the sedimentary sequence. We suggest therefore that the abundance of these species is more controlled by low availability of fresh organic matter than substratum.

Accordingly, Lopphavet was strongly influenced by the NAC during the early-middle Holocene (assemblage FH1 and FH2A). The early coral settlement was triggered by favorable sea-floor conditions with high nutrient availability, warmer, normal saline and well-oxygenated waters, and strong bottom currents. The stronger influence of Atlantic waters during the early Holocene in the northern Seas has also been demonstrated by Koç et al. (2002), Hald et al. (2004), and Lubinski et al. (1996). The progressive weaker influence of the Atlantic water during the Holocene suggested by our assemblages was also reported from Ingoydjupet around 7500-6800 cal. yr BP (Aagaard-Sørensen et al., 2010).

In Stjernsund, Joseph et al. (2013) showed that a benthic foraminiferal fauna turnover occurred at ca. 5000 cal. yr BP coinciding with fluctuating benthic oxygen isotopes values. They attribute this fluctuating pattern of oxygen isotopes to reduced inflow of Atlantic water into the fjord, and to the reduced water depth resulting from the isostatic uplift which, in turn increased the heat transfer to the atmosphere (see also López Correa et al., 2012). Joseph et al. (2013) report also a gradual bottom water cooling of $4{ }^{\circ} \mathrm{C}$ marked by a drop in benthic foraminifera diversity and by the increasing dominance of polar and arctic species between ca. 200 and 2500 cal. yr BP. They attributed this major cooling to the climate deterioration related to increased influence of arctic polar air masses and to the weakening of the Atlantic water influx in the fjord basin.

Calvo et al. (2002) show a gradual warming with highest temperatures between 12,000 and 5800 cal. yr BP and cooling of surface waters between $5800 \mathrm{cal}$. yr BP at Vøring Plateau and, based on alkenones sea surface temperature reconstructions (Fig. 8). They link this cooling to the progressive decrease in summer insolation during the Holocene (Fig. 8) and to reduced North Atlantic heat transport to the Nordic Seas.

Hald et al. (2003) report a major cooling of sea-floor and surface waters in Northern Norway during the late Holocene, between 5000-1900 cal. yr BP and a bottom water temperature drop from $10{ }^{\circ} \mathrm{C}$ to $6{ }^{\circ} \mathrm{C}$ in the Malangen fjord. Similar temperature decreases have been observed in the northern hemisphere and correlated to the Neoglacial cooling event (Hald et al., 2007; Svendsen and Mangerud, 1997; Rasmussen and Thomsen, 2010; Aagaard-Sørensen et al., 2011). Terrestrial paleorecords based on equilibrium-line altitude (ELA) have shown that glaciers in the Northern Folgefonna (mid-Norway) reformed at ca. 5200 cal. yr BP and increased progressively in size until the present (Bakke et al., 2005: Fig. 8).

\subsection{Ostracoda: ecological implications}

The ostracod taxa recorded in both cores are largely tolerant of temperature fluctuations, though all may be attributed to the cold ("frigid") to temperate regime (e.g., Hazel, 1968, 1970; Neale and Howe, 1975; Brouwers et al., 2000). Cold species like Normanicythere leioderma and Robertsonites tuberculata are generally abundant in Arctic waters (Cronin, 1981; Neale and Howe, 1975). Cronin (1981) also cites temperature ranges from 0 to $14-19{ }^{\circ} \mathrm{C}$ for characteristic species (e.g., Heterocyprideis sorbyana, Normanicythere leioderma, Acanthocythereis dunelmensis, Elofsonella concinna) occurring in the glacial assemblage OGA1 to OGA3 in core POS 391 559/3 (Fig. 8). Neale and Howe (1975) define Recent biogeographical, north-south distributed European ostracod provinces based on the most common taxa. These bioprovinces mirror the age-succession of the main ostracod assemblages in both of our cores. The "arctic" province features taxa as Normanicythere 
leioderma, Robertsonites tuberculata and Finmarchinella barentzovoensis, equivalent to the glacial assemblage in core POS $391559 / 3$ (Fig. 8). The adjacent "Norwegian", "warmer" province to the south features Pterygocythereis mucronata, Muellerina abyssicola and Thaerocythere crenulata. The latter two species are dominant in the final assemblage OA3 of core POS 391 559/2 (Fig. 7). Pterygocythereis jonesii as characteristic species from the "Celtic" province still further to the south hints towards even more increased temperatures in the interglacial assemblage of core POS $391559 /$ 3 (Fig. 8), and the assemblages OA1a-2 in core POS 391 559/2 (Fig. 7). Cytherella spp. and Krithe spp. have been described to be more abundant in the interglacial assemblage from the Rockall Plateau (Didié and Bauch, 2000). Both genera occur nearly exclusively in the interglacial assemblages of both cores.

Contradictory references point to the salinity-change tolerance of several taxa, with only Heterocyprideis sorbyana consistently listed as euryhaline species (e.g., Neale and Howe, 1975; Majoran and Nordberg, 1997; Brouwers et al., 2000; Stepanova, 2006). The presence of this species in assemblages GA 2-3 in the core POS 391 $559 / 3$ may either relate to lowered salinities or ice-raft induced contamination (as discussed in Stepanova, 2006).

Characteristic taxa as Robertsonites tuberculata, Elofsonella concinna, Bairdia inflata, Acanthocythereis dunelmensis, Finmarchinella spp. and Heterocyprideis sorbyana represent "shallow water" or "platform" environments (Coles et al., 1996; Majoran and Nordberg, 1997; Freiwald and Mostafawi, 1998; Stepanova, 2006). A deepening probably takes place in the interglacial assemblages, based on the depth ranges given for Cytherella serratula (462-1070 m) and Bythocypris affinis (347-1034 m) in Coles et al. (1996). Freiwald and Mostafawi (1998) record Cytherella abyssorum and Argilloecia conoidea as dominating faunal elements from a fjord trough deeper than $400 \mathrm{~m}$ offshore of northern Norway. The high abundance of the shelf taxa Muellerina abyssicola and Thaerocythere crenulata and the disappearance of Cytherella serratula in the final assemblage OA3 of core POS 391 559/2 suggest a final shallowing-up. Mills et al. (2009) have demonstrated that a major marine regression occurred in the area of the Lofoten (Northern Norway) during the late Holocene.

In summary, a succession of global and regional paleoceanographic events can be observed in both cores. In core POS 391 559/3 the glacial assemblages with low species richness (GA1 and GA3-4) coincide with the D-event and the Younger Dryas respectively (Fig. 8). An abrupt shift in ostracod assemblages and a gradual increase in species richness occurs at the end of the Younger Dryas, indicating warmer and probably deeper conditions until around 4000 yr BP. Post-glacial (shallowing-up) rebound in concert with a moderate cooling may be responsible for the final change in assemblage OA3 of core POS 391 559/2 (Fig. 7).

\section{Conclusions}

The detailed lithological, micropaleontological and geochemical investigations on the two cores POS391 559/2, and POS391 $559 / 3$ revealed the environmental history of Lopphavet (Northern Norway) during the last $15,000 \mathrm{yr}$.

In particular, the AMS ${ }^{14} \mathrm{C}$ dating on the benthic species Discanomalina coronata revealed the ages of the main lithological changes in core Core POS391 559/3 corresponding to the passage from the last glacial episode to a cold-water coral reef setting prior to $10,725 \pm 205 \mathrm{cal}$. yr BP. The glacial sediments were deposited from $15,300 \pm 550$ cal. yr BP to $10,725 \pm 205$ cal. yr BP, they are generally characterized by fine silt with several intercalation of dropstone layers. Benthic foraminifera provide evidence for early glaciomarine conditions at Lopphavet around 15,300 cal. yr BP.
Benthic foraminifera and ostracoda allow the interpretation of four environmental settings in core POS391 559/3:

1) The assemblages at the base of the core record glacial conditions with possibly permanent ice covers. At the sea floor the arctic benthic foraminiferal species $C$. reniforme and $E$. excavatum f. clavata dominate.

2) The passage to relatively warmer and more saline conditions within the glacial episode is indicated by an assemblage dominated by N. labradorica, A. galloway, C. pachyderma and C. ungerianus, and the ostracod species Normanicythere leioderma, Finmarchinella logani and Elofsonella concinna. This assemblage reflects also an increased influence of the warmer and more saline water of the NAC.

3) The Younger Dryas at Lopphavet is characterized by numerous iceberg and meltwater discharges but the cooling did not considerably affect the bottom water.

4) A highly diversified benthic foraminiferal assemblage typical of CWCs with abundant epifaunal benthic foraminifera species such as $D$. coronata, C. pachyderma and infaunal $U$. peregrina and $M$. barleeanum together with ostracod species Pterigocythereis mucronata, Pterigocythereis jonesi, Cytherella abyssorum characterize the coral-rich sediments at the top of the core.

Core POS391 559/2 records only the CWC from $10,600 \pm 120$ cal. yr BP to $2020 \pm 150$ cal. yr BP. Benthic foraminifera assemblages consisting of abundant warm Atlantic species such as $C$. laevigata, A. angulosa, $U$. peregrina, $M$. barleeanum record the warmest and most productive waters during the early-middle Holocene. The assemblages also suggest a progressive cooling of bottom waters toward the top of the core, decreasing flow of organic matter to the sea floor and an intensification of bottom currents.

Finally our study demonstrates that also ostracod assemblages may be used to characterize on- and off-CWC reef facies.

\section{Acknowledgments}

A warm thanks goes to the organizers of the ISDSC 2103, who gave the authors the opportunity to present and publish this research. SS and CS thank the funding from Swiss National Science Foundation Grants 200021-103482 and 200020-131829/1.

AR acknowledges funding by Deutsche Forschungsgemeinschaft (DFG), Projects TRISTAN, and Palaeo-TRISTAN (Contract Nos. Du129/ 37-2 and 37-3), and the Research Network Programme (RNP) of the European Science Foundation (ESF) "COCARDE-ERN" (2011-2016, www.esf.org/cocarde) and the International Coordination Action "COCARDE-ICA" under the auspices of IOC-UNESCO and supported by the Research Foundation-Flanders FWO (2009-2015, www. cocarde.eu).

We also thank the Captain, chief scientist, crew and scientific party of the cruise POSEIDON 391.

\section{Appendix. Supplementary Material}

Supplementary data associated with this article can be found in the online version at http://dx.doi.org/10.1016/j.dsr2.2013.07.009.

\section{References}

Aagaard-Sørensen, S., Husum, K., Hald, M., Knies, J., 2010. Paleoceanographic development in the SW Barents Sea during the Late Weichselian-Early Holocene transition. Quat. Sci. Rev. 29, 3442-3456.

Aagaard-Sørensen, S., Husum, K., Hald, M., Marchitto, T., Godtliebsen, F., 2011. Atlantic Water Influx in the Nordic Seas Over the Past 14.000 cal yr BP: Mg/Ca paleotemperature reconstructions (Ph.D. thesis). 
Bakke, J., Lie, Ø., Dahl, S.O., Paasche, Ø., 2005. Utilizing physical sediment variability in glacier-fed lakes for continuous glacier reconstructions during the Holocene, northern Folgefonna, western Norway. The Holocene 15 (2), 161-176.

Bakke, J., Lie, Ø., Heegaard, E., Dokken, T., Haug, G.H., Birks, H.H., Dulski, P., Nilsen, T. 2009. Rapid oceanic and atmospheric changes during the Younger Dryas cold period. Nat. Geosci. 2 (3), 202-205.

Basso, D., Spezzaferri, S., 2000. Distribution of living (stained) benthic foraminifera in the Iskenderun Bay (Eastern Turkey): A statistical approach. Boll. Soc. Paleontol. Ital. 39 (3), 359-379.

Berger, A., Loutre, M.F., 1991. Insolation values for the climate of the last 10 million years. Quat. Sci. Rev. 10 (4), 297-317.

Berner, H., Wefer, G., 1994. Clay-mineral flux in the Fram Strait and Norwegian Sea. Mar. Geol. 116, 327-345.

Blindheim, J., 1990. Arctic intermediate water in the Norwegian Sea. Deep-Sea Res. $35,1475-1489$

Broecker, W.S., Andree, M., Wolfli, W., Oeschger, H., Bonani, G., Kennet, J., Peteet, D., 1988. The chronology of the last deglaciation: implications to the cause of the Younger Dryas event. Paleoceanography 3, 1-19.

Bronk Ramsey, C., 2005. OxCal Program, v3. University of Oxford Radiocarbon Accelerator Unit, Oxford p. 10. (Manual).

Brouwers, E.M., Cronin, T.M., Horne, D.J., Lord, A.R., 2000. Recent shallow marine ostracods from high latitudes: implications for late Pliocene and Quaternary palaeoclimatology. Boreas 29, 127-143.

Calvo, E., Grimalt, J., Jansen, E., 2002. High resolution $\mathrm{U}_{37}^{\mathrm{K}}$ sea surface temperature reconstruction in the Norwegian Sea during the Holocene. Quat. Sci. Rev. 21 $1385-1394$.

Caralp, M.H., 1989. Abundance of Bulimina exilis and MeIonis barleeanum: relationship to the quality and quantity of organic matter. Geo-Mar. Lett. 9, 37-43.

Cedhagen, T., 1991. Retention of chloroplasts and bathymetric distribution in the sublittoral foraminifera Nonionella labradorica. Ophelia 33, 17-30.

Clarke, K.R., Warwick, R.M., 1994. Change in marine communities, Plymouth.

Clarke, K.R., Warwick, R.M., 2001. Change in marine communities: an approach to statistical analysis and interpretation, PRIMER-E, Plymouth.

Clifford, D.H.T., Stephenson, W., 1975. An Introduction to Numerical Classification. Academic Press, New York

Coles, G.P., Ainsworth, N.R., Whatley, R.C., Jones, R.W., 1996. Foraminifera and ostracoda from Quaternary carbonate mounds associated with gas seepage in the Porcupine Basin, offshore western Ireland. Rev. Esp. Micropaleontol. 28 (2), 113-151.

Corliss, B.H., Chen, C., 1988. Morphotypepattern of Norwegian Sea, deep sea benthic foraminifera and ecological implications. Geology 16, 716-719.

Corner, G.D., Steinsund, P.I., Aspeli, R., 1996. Distribution of recent benthic foraminifera in a subarctic fjord-delta: Tana, Norway. Mar Geol. 134, 113-125.

Cronin, T.M., 1981. Paleoclimatic implications of Late Pleistocene marine ostracodes from the St. Lawrence lowlands. Micropaleontology 27 (4), 384-418.

Davies, A.J., Duineveld, G.C.A., Lavaleye, M.S.S., Bergman, M.J.N., van Haren, H., Roberts, J.M., 2009. Downwelling and deep-water bottom currents as food supply mechanisms to the cold-water coral Lophelia pertusa (Scleractinia) at the Mingulay Reef complex. Limnol. Oceanogr. 54, 620-629.

Didié, C., Bauch, H.A., 2000. Species composition and glacial-interglacial variations in the ostracode fauna of the northeast Atlantic during the past 200,000 years. Mar. Micropaleontol. 40, 105-129.

Dons, C., 1944. Norway's coral reefs (in Norwegian). Nor. Vidensk. Selsk. Trondheim Forh. 16A, 37-82.

Dorschel, B., Hebbeln, D., Rüggeberg, A., Dullo, W.C., Freiwald, A., 2005. Growth and erosion of a cold-water coral covered carbonate mound in the Northeast Atlantic during the late Pleistocene and Holocene. Earth Planet. Sci. Lett. 233, $33-44$.

Dorschel, B., Hebbeln, D., Foubert, A., White, M., Wheeler, A.J., 2007. Hydrodynamics and cold-water coral facies distribution related to recent sedimentary processes at Galway Mound west of Ireland. Mar. Geol. 244, 184-195.

Duineveld, G.C.A., Lavaleye, M.S.S., Berghuis, E.M., 2004. Particle flux and food supply to a seamount cold-water coral community (Galicia Bank, NW Spain). Mar. Ecol. Prog. Ser. 277, 13-23.

Dullo, W.-Chr, Flögel, S., Rüggeberg, A., 2008. Cold-water coral growth in relation to the hydrography of the Celtic and Nordic European continental margin. Mar Ecol. Prog. Ser. v. 371, 165-171.

Eide, L., 1979. Evidence of a topograpllicnlly trapped vortex on the Norwegian continental shelf. Deep-Sea Res. 26 (6.4), 601-621.

Elverhøi, A., Liestøl, O., Nagy, J., 1980. Glacial erosion, sedimentation and microfauna in the inner part of Kongsfjord, Spitsbergen. In: Geological and geophysical research in Svalbard and on Jan Mayen. Nor. Polarinst. Skr. 172, 33-61.

Erbs-Hansen, D.R., Knudsen, K.L., Gary, A.C., Jansen, E., Gyllencreutz, G., Scao, V. 2011. Late Younger Dryas and early Holocene palaeoenvironments in Skagerrak, eastern North Atlantic: a multiproxy study. Boreas 40, 660-680.

Fairbanks, R.G., 1989. A 17,000-year glacio-eustatic sea level record: influence of glacial melting rates on the Younger Dryas event and deep-ocean circulation. Nature 342, 637-642.

Fairbanks, R.G., Charles, C.D., Wright, J.D., 1992. Origin of global meltwater pulses. In: Long, Kra (Eds.), Four Decades of Radiocarbon Studies. Springer pp. 473-500.

Field, J.G., Clarke, K.R., Warwick, R.M., 1982. A practical strategy for analysing multispecies distribution patterns. Mar. Ecol. Prog. Ser. 8, 37-52.

Feyling-Hanssen, R.W., 1964. Foraminifera in Late Quaternary deposits from the Oslofjord area. Nor. Geol. Unders., 225-383.
Fosså, J.H., Mortensen, P.B., Furevik, D.M., 2000. Lophelia coral reefs along the Norwegian coast. Occurrence and conditions (in Norwegian). Fisken Havet 2 , $1-94$

Fosså, J.H., Mortensen, P.B., Furevik, D.M., 2002. The deep-water coral Lophelia pertusa in Norwegian waters: distribution and fishery impacts. Hydrobiologia $471,1-12$.

Fosså, J.H., Lindberg, B., Christensen, O., Lundälv, T., Svellingen, I., Mortensen, P.B., Alvsvåg, J., 2005. Mapping of Lophelia reefs in Norway: experiences and survey methods. In: Freiwald, A., Roberts, J.M. (Eds.), Cold-Water Corals and Ecosystems. Springer-Verlag, pp. 359-391.

Freiwald, A., Heinrich, R., Pätzold, J., 1997. Anatomy of a deep-water coral reef mound from Stjernsund, West-Finnmark, northern Norway. In: James, N., Clarke, J. (Eds.), Cool-Water Carbonates. SEPM Special Publication, pp. 141-161.

Freiwald, A., Mostafawi, N., 1998. Ostracods in a cold-temperate coastal environment, Western Troms, Northern Norway: sedimentary aspects and assemblages. Facies 38 (1), 255-273.

Freiwald, A., Wilson, J.B., Henrich, R., 1999. Grounding Pleistocene icebergs shape recent deep-water coral reefs. Sediment. Geol. 125, 1-8.

Freiwald, A., 2002. Reef-forming cold-water corals. In: Wefer, G., Billett, D., Hebbeln, D., Jørgensen, B.B., Schlüter, M., van Weering, T. (Eds.), Ocean Margin Systems. Springer-Verlag, Berlin, Heidelberg.

Freiwald, A., Hühnerbach, V., Lindberg, B., Wilson, J.B., Campbell, J., 2002. The Sula Reef Complex, Norwegian shelf. Facies 47, 179-200.

Freiwald, A., Fosså, J.H., Grehan, A., Koslow, T., Roberts, J.M., 2004. Cold-Water Coral Reefs. UNEP-WCMC, Cambridge, pp. 1-84.

Garvine, R.W., 1995. A dynamical system for classifying buoyant coastal discharges. Cont. Shelf Res. 15, 1585-1596.

Grasshoff, K., Ehrhardt, M., Kremling, K., 1983. Methods of Seawater Analysis, 2nd Ed. Verlag Chemie, Weinheim p. 419.

Grøsfjeld, K., Funder, S., Seidenkrantz, M.-S., Glaister, C., 2006. Last Interglacial marine environments in the White Sea region, north-western Russia. Boreas 35, 493-520.

Gunnerus, J.E., 1768. Om nogle Norske coraller. Kongl. Nor. Vidensk. Selsk. Skrift. 4, $38-73$.

Gustafsson, M., Nordberg, K., 1999. Benthic foraminifera and their response to hydrography, periodic hypoxic conditions and primary production in the Koljo fjord on the Swedish west coast. J. Sea Res. 41 (3), 163-178.

Hajdas, I., Bonani, G., Zimmerman, S.H., Mendelson, M., Hemming, S., 2004a. C-14 ages of ostracodes from Pleistocene lake sediments of the western Great Basin, USA-results of progressive acid leaching. Radiocarbon 46, 189-200.

Hajdas, I., Bonani, G., Thut, J., Leone, G., Pfenninger, R., Maden, C., 2004b. A report on sample preparation at the ETH/PSI AMS facility in Zurich. Nucl. Instrum. Methods B 223-224, 267-271.

Hald, M., Vorren, T.O., 1987a. Foraminiferal stratigraphy and environments of Late Weichselian deposits on the continental shelf off Troms, Norhtern Norway. Mar. Micropaleontol. 12, 129-160.

Hald, M., Vorren, T.O., 1987b. Stable isotope stratigraphy and paleoceanography during the last déglaciation on the continental shelf off Troms, northern Norway. Paleoceanography 2, 583-599.

Hald, M. Danielsen, T.K., Lorentzen, S., 1989. Late Pleistocene-Holocene benthic foraminiferal distribution in the southwestern Barents Sea-Paleoenvironmental implications. Boreas 18, 367-388.

Hald, M, Steinsund, P.I., 1992. Distribution of surface sediment benthic foraminifera in the southwestern Barents Sea. J. Foraminiferal Res. 22, 347-362.

Hald, M., Steinsund, P.I., Dokken, T., Korsun, S., Polyak, L., Aspeli, R., 1994. Recent and Late Quaternary distribution of Elphidium excavatum F. clavatum in Arctic seas. Cushman Found. Spec. Publ. 32, 141-153.

Hald, M., Korsun, S., 1997. Distribution of modern benthic foraminifera from fjords of Svalbard, European Arctic. J. Foraminiferal Res. 27 (2), 101-122.

Hald, M., Aspeli, R., 1997. Rapid climatic shifts of the northern Norwegian Sea during the last deglaciation and the Holocene. Boreas 26, 15-28.

Hald, M., Hagen, S., 1998. Early Preboreal cooling in the Nordic seas region triggered by meltwater. Geology 26, 615-618.

Hald, M., Husum, K., Vorren, T.O., Grøsfjeld, K., Jensen, H.B., Sharapova, A., 2003. Holocene climate in the subarctic fjord Malangen, northern Norway: a multiproxy study. Boreas 32, 543-559.

Hald, M., Ebbesen, H., Forwick, M., Godtliebsen, F., Khomenko, L., Korsun, S., Ringstad, O., Lena, Vorren, T.O., 2004. Holocene paleoceanography and glacial history of the West Spitzbergen area, Euro-Arctic margin. Quat. Sci. Rev. 23 (2021), 2075-2088

Hald, M., Andersson, C., Ebbesen, H., Jansen, E., Klitgaard- Kristensen, D., Risebrobakken, L., Salomonsen, G.R., Sarnthein, M., Sejrup, H.P., Telford, R.J., 2007. Variations in temperature and extent of Atlantic Water in the northern North Atlantic during the Holocene. Quat. Sci. Rev. 26, 3423-3440.

Hansen, A., Knudsen, K.L., 1995. Recent foraminiferal distribution in Freemansundet and Early Holocene stratigraphy on Edgeoya, Svalbard. Polar Res. 14, 215-238.

Hazel, J.E., 1968. Pleistocene ostracode zoogeography in Atlantic Coast submarine canyons. J. Paleontol. 42 (5), 1264-1271.

Hazel, J.E., 1970. Atlantic continental shelf and slope of the United StatesOstracode zoogeography in the southern Nova Scotia and northern Virginian faunal provinces. Geol. Surv. Prof. Pap. 529E, 1-21.

Hebbeln, D., Knudsen, K.L., Gyllencreutz, R., Kristensen, P., Klitgaard-Kristensen, D., Backman, J., 2006. Late Holocene coastal hydrographic and climate changes in the eastern North Sea. The Holocene 16, 987-1001.

Hovland, M., Mortensen, P.B., 1999. Norwegian Coral Reefs and Processes in the Seafloor (in Norwegian). John Grieg, Bergen. 
Hovland, M., Mortensen, P.B., Brattegard, T., Strass, P., Rokoengen, K., 1998. Ahermatypic coral banks of mid-Norway: evidence for a link with seepage of light hydrocarbons. Palaios 13, 189-200.

Hovland, M., Mortensen, P.B., Thomsen, E., Brattegard, T., 1997. Substratum-related ahermatypic corals on the Norwegian continental shelf, in Proceedings, 8th International Coral Reef Symposium, Smithsonian Tropical Research Institute: Panama City, pp. 1203-1206.

Hovland, M., Vasshus, S., Indreeide, A., Austdal, L., Nilsen, Ø., 2002. Mapping and imaging deep-sea coral reefs off Norway, 1982-2000. Hydrobiologia 471, 13-17.

Hovland, M., Jensen, S., Indreiten, T., 2012. Unit pockmarks associated with Lophelia coral reefs off mid-Norway: more evidence of control by 'fertilizing' bottom currents. Geo-Mar. Lett. 32, 545-554.

Huvenne, V.A.I., Masson, D.G., Wheeler, A.J., 2009. Sediment dynamics of a sandy contourite: the sedimentary context of the Darwin cold-water coral mounds, Northern Rockall Trough. Int. J. Earth Sci. 98, 865-884.

Jennings, A., Syvitski, J., Gerson, L., Grönvold, K., Geirsdottir, A., Hardardottir, J., Andrews, J., Hagen, S., 2000. Chronology and paleoenvironments during the late Weichselian deglaciation of the south-west Iceland shelf. Boreas 29, 167-183.

Joseph, N., López Correa, M., Schönfeld, J., Rüggeberg, A., Freiwald, A., 2013. Subarctic Holocene climatic and oceanographic variability in Stjernsund, Northern Norway: evidence from benthic foraminifera and stable isotopes. Boreas 42 (3), 511-531.

Junttila, J., Aagaard-Sørensen, S., Husum, K., Hald, M., 2010. Late Glacial-Holocene clay minerals elucidating glacial history in the SW Barents Sea. Mar. Geol. 276 71-85.

Kaiho, K., 1994. Benthic foraminiferal dissolved-oxygen index and dissolved-oxygen levels in the modern ocean. Geology 22, 719-722.

Keigwin, L.D., Jones, G.A., Lehman, S.J., 1991. Deglacial meltwater discharge, North Atlantic deep circulation, and abrupt climatic change. J. Geophys. Res. 96, 16811-16826.

Klitgaard-Kristensen, D., Sejrup, H.P., 1996. Modern benthic foraminiferal biofacies across the northern North Sea. Sarsia 81, 97-106.

Klitgaard-Kristensen, D., Sejrup, H.P., Haflidason, H., 2002. Distribution of recent calcareous benthic foraminifera in the northern North Sea and relation to the environment. Polar Res. 21 (2), 275-282.

Knies, J., 2005. Climate-induced changes in sedimentary regimes for organic matter supply on the continental shelf off northern Norway. Geochim. Cosmochim. Acta 69 (19), 4631-4647.

Koç, N., Kristensen, D.K., Hasle, K., Forsberg, C.F., Solheim, A., 2002. Late glacial paleoceanography of Hinlopen Strait, northern Svalbard. Polar Res. 21 (2), 307-314.

Korsun, S., Hald, M., 1998. Modern benthic foraminifera off Novaya Zemlya tidewater glaciers, Russian Arctic. Arct. Alp. Res. 30 (1), 61-77.

Korsun, S., Hald, M., 2000. Seasonal dynamics of benthic foraminifera in a glacially fed fjord of Svalbard, European Arctic. J. Foraminiferal Res. 30 (4), 251-271.

Kruskal, J.B., 1964. Multidimensional scaling by optimizing goodness of fit to a nonmetric hypothesis. Psychometrika 29, 1-27.

Kruksal, J.B., Wish, M., 1978. Multidimensional Scaling. Sage Publication, Beverly Hills, California.

Kubischta, F., Knudsen, K.L., Kaakinen, A., Salonen, V.-P., 2010. Late Quaternary foraminiferal record in Murchisonfjorden, Nordaustlandet, Svalbard. Polar Res. 29, N.3.

Kubischta, F., Knudsen, K.L., Ojala, A.E.K., Salonen, V.-P., 2011. Holocene benthic foraminiferal record from a high-arctic fjord, Nordaustlandet, Svalbard. Geografiska Annaler. Series A. Phys. Geogr. 93, 227-242.

Laberg, J.S., Andreassen, K., Vorren, T.O., 2012. Late Cenozoic erosion of the highlatitude southwestern Barents Sea shelf revisited. Geol. Soc. Am. Bull. 124 (1-2), 77-88.

Lambeck, K., Yokoyama, Y., Purcell, T., 2002. Into and out of the last glacial maximum: sea-level changes during oxygen isotope stages 3 and 2. Quat. Sci. Rev. 21, 1-3.

Landvik, J.Y., Bondevik, S., Elverhoi, A., Fjeldskaar, W., Mangerud, J., Salvigsen, O., Siegert, M.J., Svendsen, J.-I., Vorren, T.O., 1998. The last glacial maximum of Svalbard and the Barents sea area: ice sheet extent and configuration. Quat. Sci. Rev. 17, 43-75.

Lehman, S.J., Keigwin, L.D., 1992. High resolution record of the North Atlantic drift 14-8 kyr BP: implications for climate, circulation and ice sheet melting. Nature 356, 757-762.

Lindberg, B., Mienert, J., 2005. Sedimentological and geochemical environment of the Fugløy Reef off northern Norway. In: Freiwald, A., Roberts, J.M. (Eds.), ColdWater Corals and Ecosystems. Springer-Verlag, pp. 633-650.

Lindberg, B., Berndt, C., Mienert, J., 2007. The Fugloy Reef at 70N; acoustic signature, geologic, geomorphologic and oceanographic setting. Int. J. Earth Sci. 96 (1), 201-213.

Linke P., Lutze G.F., 1993. Microhabitats of benthic foraminifera-a static concept or a dynamic adaptation to optimize food acquisition? In: Langer, M.R., (Ed.). Foraminiferal Microhabitats, Marine Micropaleontology, vol. 20, pp. 215-234.

Ljoen, R., Nakken, O., 1969. On the hydrography of the shelf waters off More and Helgeland. FiskDir. Skt-. Ser. HavUnders. 15, 285-294.

Loeng, H., 1991. Features of the physical oceanographic conditions of the Barents Sea. Pp. S 1 8. In: Sakshaug, E., Hopkins, C.C.E., Britsland, N.A. (Eds.), Proceedings of the Pro Mare Symposium on Polar Marine Ecology, Trondheim, 12-16 May 1990, Polar Research, 10/1.

López Correa, M., Montagna, P., Joseph, N., Rüggeberg, A., Fietzke, J., Dorschel, B., Goldstein, S.L., Wheeler, A., Freiwald, A., 2012. Preboreal onset of Norwegian cold-water coral growth beyond the Arctic Circle revealed by radiocarbon and U-series dating and neodymium isotopes. Quat. Sci. Rev. 34, 24-43.

Louchouarn, P. Lucotte, M. Duchemin, E, de Vernal, A., 1997. Early diagenetic processes in recent sediments of the Gulf of St-Lawrence: phosphorus, Carbon, and Iron burial rates. Mar. Geol. 139 (1/4), 181-200.

Loubere, P., 1996. The surface ocean productivity and bottom water oxygen signals in deep water benthic foraminiferal assemblages. Mar. Micropaleontol. 28, 247-261.

Lubinski, D.J., Korsun, S., Polyak, L., Forman, S.L., Lehman, S.J., Herlihy, F.A., Miller, G.H., 1996. The last deglaciation of the Franz Victoria Trough, northern Barents Sea. Boreas 25, 89-100.

Lubinski, D.J., Polyak, L., Forman, S.L., 2001. Freshwater and Atlantic water inflows to the deep northern Barents and Kara seas since ca $1314 \mathrm{C}$ ka: foraminifera and stable isotopes. Quat. Sci. Rev. 20, 1851-1879.

Lutze, G.F., Thiel, H., 1989. Epibenthic foraminifera from elevated microhabitats: Cibicidoides wuellerstorfi and Planulina ariminensis. J. Foram. Res. 19, 153-158.

Mackensen, A., Sejrup, H., Jansen, E., 1985. The distribution of living benthic foraminifera on the continental slope and rise off Southwest Norway. Mar. Micropaleontol. 9, 275-306.

Mackensen, A., Hald, M., 1988. Cassidulina teretis Tappan and C. laevigata d'Orbigny: their modern and late Quaternary distribution in northern seas. J. Foraminiferal Res. 18, 16-24

Mackensen, A., Schmiedl, D.K., Harloff, J., Giese, M., 1995. Deep-sea foraminifera in the South Atlantic Ocean: ecology and assemblage generation. Mar. Micropaleontol. 41, 342-358.

Majoran, S., Nordberg, K., 1997. Late Weichselian ostracod assemblages from the southern Kattegat, Scandinavia: a palaeoenvironmental study. Boreas 26, $181-200$.

Mangerud, J., Andersen, S.T., Berglund, B.E., Donner, D.D., 1974. Quaternary stratigraphy of Norden, a proposal for terminology and classification. Boreas 3, 109-128.

Margreth, S., Rüggeberg, A., Spezzaferri, S., 2009. Benthic foraminifera as bioindicator for cold-water coral reef ecosystems along the Irish margin. Deep-Sea Res. I 56, 2216-2234.

Margreth, S., Gennari, G., Rüggeberg, A., Comas, M.C., Pinheiro, L.M., Spezzaferri, S., 2011. Growth and demise of cold-water coral ecosystems on mud volcanoes in the West Alboran Sea: the messages from the planktonic and benthic foraminifera. Mar. Geol. 282 (1-2), 26-39.

Mienis, F., de Stigter, H.C., White, M., Duineveld, G., de Haas, H., van Weering, T.C.E., 2007. Hydrodynamic controls on cold-water coral growth and carbonatemound development at the SW and SE Rockall Trough Margin, NE Atlantic Ocean. Deep-Sea Res. I 54, 1655-1674.

Mikalsen, G., Sejrup, H.P., Aarseth, I., 2001. Late-Holocene changes in ocean circulation and climate: foraminiferal and isotopic evidence from Sulafjord, western Norway. The Holocene 11, 437-446.

Mikkelsen, N., Erlenkeuser, H., Killingley, J.S., Berger, W.H., 1982. Norwegian corals: radiocarbon and stable isotopes in Lophelia pertusa. Boreas 11 (2), 163-171.

Mills, K., Mackay, A.W., Bradley, R.S., Finney, B., 2009. Diatom and stable isotope records of late-Holocene lake ontogeny at Indrepollen, Lofoten, NW Norway: a response to glacio-isostasy and Neoglacial cooling. The Holocene 19, 261.

Mitchelson-Jacob, G., Sundby, S., 2001. Eddies of Vestfjorden, Norway. Cont. Shelf Res. 21, 1901-1918.

Mork, M., 1981. Circulation phenomena and frontal dynamics of the Norwegian coastal current. Phil. Trans. R. Soc. London A 302, 635-647.

Mortensen, P.B., Hovland, M.T., Brattegard, T., Farestveit, R., 1995. Deep water bioherms of coral Lophelia pertusa at 64 degrees on the Norwegian shelf: structure and associated megafauna. Sarsia 80, 145-158.

Mortensen, P.B., Hovland, M.T., Fosså, J.H., Furevik, D.M., 2001. Distribution, abundance and size of Lophelia pertusa coral-reefs in mid-Norway in relation to seabed characteristics. J. Mar. Biol. Assoc. U.K. 81, 581-597.

Moseidjord, H., Svendsen, H., Slagstad, D., 1999. Sensitivity studies of circulation and ocean-shelf exchange off northern Norway. Sarsia 84, 191-198.

Murray, J.W., 1991. Ecology and Palaeoecology of Benthic Foraminifera. Longman, Harlow.

Murray, J.W., 2006. Ecology and Applications of Benthic Foraminifera. Cambridge University Press, Cambridge p. 426.

Neale, J.W., Howe, H.V., 1975. The marine ostracoda of Russian Harbour, Novaya Zemlya and other high latitude faunas. Am. Paleontol. Bull. 65, 381-431.

Orvik, K.A., Skagseth, Ø., Mork, M., 2001. Atlantic inflow to the Nordic Seas: current structure and volume fluxes from moored current meters, VM-ADCP and SeaSoarCTD observations, 1995-1999. Deep-Sea Res. I Oceanogr. Res. Pap. 48 (4), 937-957.

Orvik, K.A., Niiler, P., 2002. Major pathways of Atlantic water in the northern North Atlantic and Nordic Seas toward Arctic. Geophys. Res. Lett. 29 (19), 1896, http: //dx.doi.org/10.1029/2002GL015002. (2002).

Østby, K.L., Nagy, J., 1982. Foraminiferal distribution in the western Barents Sea, Recent and Quaternary. Polar Res., 53-87.

Ottesen, D., Dowdeswell, J.A., Rise, L., 2005. Submarine landforms and the reconstruction of fast-flowing ice streams within a large Quaternary ice sheet: the $2500 \mathrm{~km}-\mathrm{long}$ Norwegian-Svalbard margin (57.8N to 80.8N). Geol. Soc. Am. Bull. 117 (5/6).

Ottesen, D., Stokes, C.R., Rise, L., Olsen, L., 2008. Ice-sheet dynamics and ice streaming along the coastal parts of northern Norway. Quat. Sci. Rev. 27, 922-940.

Polyak, L., Mikhailov, V., 1996. Post-glacial environments of the southeastern Barents Sea: foraminiferal evidence. In: Andrews, J.T., et al. (Eds.), Late 
Quaternary Paleoceanography of the North Atlantic Margins, 111. Geological Society Special Publications, pp. 323-337.

Polyak, L., Levitan, M., Khusid, T., et al., 2000. The impact of glaciation, riverdischarge, and sea-level change on Late Quaternary environments in the southwestern Kara Sea. Int. J. Earth Sci., 89/3.

Polyak, L., Gataullin, V., Gainanov, V., Gladysh, V., Goremykin, Yu., 2002. Kara Sea expedition yields insight into LGM ice sheet extent. Eos 83 (46), 525-529.

Pontoppidan, E., 1755. The Natural History of The natural history of Norway, Vol A Linde, London.

Poulain, P.M., Warn-Varnas, A., Niiler, P.P., 1996. Near-surface circulation of the Nordic Seas as measured by Lagrangian drifters. J. Geophys. Res. 101 (C8), 18237-18258.

Rapp, H.T., Sneli, J.A., 1999. Lophelia pertusa-myths and realities-poster, In: Proceedings of the 2nd Nordic Marine Oceanographes Conference, Hirtshals, Denmark, 2-4. April 1999.

Rasmussen, T.L., Thomsen, E., 2010. Holocene temperature and salinity variability of the Atlantic Water inflow to the Nordic seas. The Holocene 20, 8

Rasmussen, T.L., Bäckström, D., Heinemeier, J., Klitgaard-Kristensen, D., Knutz, P.C. Kuijpers, A., Lassen, S., Thomsen, E., Troelstra, S.R., van Weering, T.C.E., 2002 The Faeroe-Shetland gateway: Late Quaternary water mass exchange between the Nordic seas and the northeastern Atlantic. Mar. Geol. 188, 165-192.

Rasmussen, T.L., Thomsen, E., Slubowska, M.A., Jessen, S., Solheim, A., Koc, N., 2007 Paleoceanographic evolution of the SW Svalbard margin $\left(76^{\circ} \mathrm{N}\right)$ since 20,000 14 C yr BP. Quat. Res. 67, 100-114.

Reimer, PJ., Baillie, M.G.L, Bard, E., Bayliss, A, Beck, J.W, Blackwell, P.G, Bronk Ramsey, C., Buck, C.E., Burr, G.S., Edwards, R.L., Friedrich, M., Grootes, P.M., Guilderson, T.P., Hajdas, I., Heaton, T.J., Hogg, A.G., Hughen, K.A., Kaiser, K.F., Kromer, B., McCormac, F.G., Manning, S.W., Reimer, R.W., Richards, D.A. Southon, J.R., Talamo, S., Turney, C.S.M., van der Plicht, J., Weyhenmeyer, C.E. 2009. IntCal09 and Marine09 radiocarbon age calibration curves, 0-50,000 Years cal BP. Radiocarbon 51, 1111-1150.

Roberts, J.M., Wheeler, A.J., Freiwald, A., 2006. Reefs of the deep: the biology and geology of cold-water coral ecosystems. Science 312, 543-547.

Rogers, A.D., 1999. The biology of Lophelia pertusa (Linnaeus 1758) and other deepwater reef-forming corals and impacts from human activities. Int. Rev. Hydrobiol. 84, 315-406.

Romundset, A., Bondevik, S., Bennike, O., 2011. Postglacial uplift and relative sea level changes in Finnmark, northern Norway. Quat. Sci. Rev. 30 (19-20).

Rüggeberg, A., Dullo, C., Dorschel, B., Hebbeln, D., 2007. Environmental changes and growth history of Propeller Mound, Porcupine Seabight: evidence from benthic foraminiferal assemblages. Int. J. Earth Sci. 96, 57-72.

Rüggeberg A., Flögel, S., Dullo, W. Chr., Hissmann, K., Freiwald, A. 2011. Water mass characteristics and sill dynamics in a polar cold-water coral reef setting at Stjernsund, northern Norway. Mar. Geol. 282, 5-12.

Ruttenberg, K.C., 1992. Development of a sequential extraction method for differen forms of phosphorus in marine sediments. Limnol. Oceanogr. 37 (7), 1460-1482.

Sætre, R., Aure, J. Ljoen, R, 1988. Wind effects on the lateral extension of the Norwegian Coastal Water. Cont. Shelf Res. 8, 239-253.

Sætre, R., 1999. Features of the central Norwegian shelf circulation. Cont. Shelf Res. 19, 1809-1831.

Sætre, R. (Ed.), 2007. The Norwegian Coastal Current-Oceanography and Climate. Tapir Academic Press, Trondheim, Norway.

Sejrup, H.P., Fjæran, T., Hald, M., Beck, L., Hagen, J., Miljeteig, I., Morvik, I., Norvik, O., 1981. Benthonic foraminifera in surface samples from the Norwegian continental margin between $62^{\circ} \mathrm{N}$ and $65^{\circ} \mathrm{N}$. J. Foraminiferal Res. 11, 277-295.

Schönfeld, J., 2002. A new benthic foraminiferal proxy for near-bottom current velocities in the Gulf of Cadiz, northeastern Atlantic Ocean. Deep-Sea Res. I 49, 1853-1875.

Schönfeld, J., Altenbach, A.V., 2005. Late glacial to recent distribution pattern of deep-water Uvigerina species in the north-eastern Atlantic. Mar. Micropaleontol. $57,1-24$.

Schönfeld, J., Dullo, W.C., Pfannkuche, O., Freiwald, A., Rüggeberg, A., Schmidt, S. Weston, J., 2011. Recent benthic foraminiferal assemblages from cold-water coral mounds in the Porcupine Seabight. Facies 57 (2), 187-213.

Schönfeld, J., Alve, E., Geslin, E., Jorissen, F., Korsun, S., Spezzaferri, S., Members of the FOBIMO group, 2012. The FOBIMO (FOraminiferal Blo-MOnitoring) initiative-towards a standardized protocol for soft-bottom benthic foraminifera monitoring studies. Mar. Micropaleontol. 94-95, 1-13.

Schröder-Ritzrau, A., Freiwald, A., Mangini, A, 2005, U/Th-dating of deep-wate corals from the eastern North Atlantic and the western Mediterranean Sea. In:
Freiwald, J.M., Roberts, J.M. (Eds.), Cold-water Corals and Ecosystems. Springer, Berlin, pp. 157-172.

Sigmond, E.M.O., 1992. Bedrock map, Norway and adjacent ocean areas. Scale 1: 3 mill. Norges geologiske undersøkelse, Trondheim.

Skagseth, O., Drinkwater, K.F., Terrile, E., 2011. Wind and buoyancy induced transport of the Norwegian Coastal Current in the Barents Sea. J. Geophys. Res. 11.

Spezzaferri, S., Rüggeberg, A., Stalder, C., Margreth, S., 2013. Benthic foraminifer assemblages from norwegian cold-water coral reefs. J. Foraminiferal Res. 43 21-39, http://dx.doi.org/10.2113/gsjfr.43.1.21.

Stefan Nees, S., Altenbach, A.V., Kassens, H., Thiede, J., 1997. High-resolution record of foraminiferal response to late Quaternary sea-ice retreat in the NorwegianGreenland Sea. Geology 25 (7), 659-662.

Steinsund, P.I., 1994. Benthic Foraminifera in Surface Sediments of the Barents and Kara Seas: Modern and Late Quaternary Applications (Ph.D. thesis), University of Tromsø, Norway (Unpublished).

Stepanova, A., 2006. Late Pleistocene-Holocene and Recent ostracoda of the Laptev Sea. Paleontol. J. 40, 91-204.

Struck, U., 1995. Stepwise postglacial migration of benthic foraminifera into the abyssal northeastern Norwegian Sea. Mar. Micropaleontol. 26, 207-231.

Sundby, S., 1984. Influence of bottom topography on the circulation at the continental shelf off northern Norway. Fiskeridir. Skr. Ser. Havunders. 17, 501-519.

Svendsen, J.I., Mangerud, J., 1997. Holocene glacial and climatic variations on Spitsbergen, Svalbard. The Holocene 7, 45-57.

Tamburini, F., Huon, S., Steinmann, P., Grousset, F.E., Adatte, T., Föllmi, K.B., 2002 Dysaerobic conditions during Heinrich events 4 and 5: evidence from phosphorus distribution in a North Atlantic deep-sea core. Geochim. Cosmochim. Acta $66,4069-4083$.

Thiem, Ø., Ravagnan, E., Fossa, J.H., Berntsen, J., 2006. Food supply mechanisms for cold-water corals along a continental shelf edge. J. Mar. Syst. 26, 1481-1495.

Thierens, M. Titschack, J., Dorschel, B., Huvenne, V.A.I., Wheeler, A.J., Stuut, J.-B. O'Donnell, R., 2010. The $2.6 \mathrm{Ma}$ depositional sequence from the Challenger cold-water coral carbonate mound (IODP Exp. 307): sediment contributors and hydrodynamic palaeo-environments. Mar. Geol. 271, 260-277.

Thomsen, E., Vorren, T.O., 1986. Macrofaunal palaeoecology and stratigraphy in late Quaternary shelf sediments off northern Norway. Palaeogeogr. Palaeoclimatol. Palaeoecol. 56, 103-150.

Thomas, E., Booth, L., Maslin, M., Shackleton, N.J., 1995. Northeastern Atlantic benthic foraminifera during the last 45,000 years: changes in productivity seen from the bottom up. Paleoceanography 10, 545-562.

Vorren, T.O Strass, IF, Lind-Hansen, OW, 1978. Late Quaternary sediments and stratigraphy on the continental shelf off Troms and west Finnmark, northern Norway. Quat. Res. 10, 340-365.

Vorren, T.O., HaId, M., Lebesbye, E., Vorren, K.-D., 1987a. Late Cenozoic stratigraphy and environment in the Barents Sea. Polar Res, 5.

Vorren, T.O, Lebesbye, E., Andreassen, K., Larsen, K.B., 1987b. Glaciogenic sediments on a passive continental margin as exemplified by the Barents Sea. Mar. Geol.

Vorren, T.O., Rokoengen, K., Bugge, T., Larsen, O.A., 1992. Kontinentalsokkelen tykkelsen på kvartære sedimenter: Nasjonaltas for Norge, map number 2.3.9: Statens Kartverk, scale 1:3,000,000.

Vorren, T.O., Laberg, J.S., Blaume, F., Dowdeswell, J.A., Kenyon, N.H., Mienert, J. Rumohr, F., 1998. The Norwegian-Greenland Sea continental margins: morphology and late Quaternary sedimentary processes and environment. Quat. Sci. Rev. 17, 273-302.

Vorren, T.O., Plassen, L., 2002. Deglaciation and palaeoclimate of the AndfjordVagsfjord area, North Norway. Boreas 31, 97-125.

Warwick, R.M., Clarke, K.R., 1991. A comparison of methods for analysing changes in benthic community structure. J. Mar. Biol. Assoc. UK 71, 225-244.

Watkins, N.D., Keany, J., Ledbetter, M.T., Huang, T.C., 1974. Antarctic glacial history from analyses of ice rafted deposits in marine sediments: new model and initial tests. Science 186, 533-536.

Winsborrow, M.C.M., Andreassen, K., Corner, G.D., Laberg, J.S., 2010. Deglaciation of a marine-based ice sheet: Late Weichselian palaeo-ice dynamics and retreat in the southern Barents Sea reconstructed from onshore and offshore glacial geomorphology. Quat. Sci. Rev. 29, 424-442.

Winsborrow, M., Stokes, C.R., Andreassen, K., 2012. Ice-stream flow switching during deglaciation of the southwestern Barents Sea. Geol. Soc. Am. Bull. 124 (3-4), http://dx.doi.org/10.1130/1330416.1. (ISSN 0016-7606.s 275-290.s).

Zajaczkowski, M., Szczucinski, W., Plessen, B., Jernas, P., 2010. Benthic foraminifera in Hornsund, Svalbard: implications for paleoenvironmental reconstructions. Pol. Polar Res. 31 (4), 349-375. 